https://doi.org/10.46344/JBINO.2020.v09i06.02

\title{
APPROACH TO ACUTE LYMPHOBLASTIC LEUKEMIA
}

Somil Singhal

Consultant Pathologist, Department of Hematology ,Kriti Pathology ( A complete Diagnostic solution) ;A unit of Kriti scanning Centre (P) Ltd, Allahabad,Uttarpradesh , India

Email:somil15feb@gmail.com

\begin{abstract}
During recent decades, understanding of the molecular mechanisms of acute lymphoblastic leukemia (ALL) has improved considerably, resulting in better risk stratification of patients and increased survival rates. Age, white blood cell count (WBC), and specific genetic abnormalities are the most important factors that define risk groups for ALL. State-of-the-art diagnosis of ALL requires cytological and cytogenetical analyses, as well as flow cytometry and high-throughput sequencing assays. An important aspect in the diagnostic characterization of patients with ALL is the identification of the Philadelphia (Ph) chromosome, which warrants the addition of tyrosine kinase inhibitors (TKI) to the chemotherapy backbone. Data that support the benefit of hematopoietic stem cell transplantation (HSCT) in high risk patient subsets or in late relapse patients are still questioned and have yet to be determined conclusive. This article presents the newly published data in ALL workup and treatment, putting it into perspective for the attending physician in hematology and oncology.
\end{abstract}

Keywords: acute lymphoblastic leukemia; clinical management; follow-u 
Background on ALL Work-Up and FollowUp

Acute leukemias are classified into acute myeloid (AML) and acute lymphoblastic leukemias (ALL), each form having a characteristic immunophenotype. Based on the cytological aspect of the blasts, there are three main types of acute lymphoblastic leukemia: L1, with small cells that have a large nucleus; L2, with larger, pleomorphic blasts; and L3, with a highly basophilic cytoplasm. The cytological classification has now been mostly replaced by the World Health Organization (WHO) classification, which divides ALLs into B-cell ALL and Tcell ALL. B-cell ALL and acute lymphoblastic lymphomas are malignancies with B-cell lymphoblasts [1-3]. When the primary disease is diagnosed in a lymph node, the correct name is "acute lymphoblastic lymphoma." In B-cell ALLS (B-ALLS), which represent around $85 \%$ of all pediatric ALLS, the bone marrow aspirate displays at least $25 \%$ bone marrow lymphoblasts [1-4]. Despite tremendous improvements in understanding the molecular mechanisms behind B-cell ALL (B-ALL), the prognosis of these patients is rather poor, especially for old or frail patients that are unable to withstand aggressive chemotherapy or allogeneic hematopoietic stem cell transplantation. Moreover, in the case of adult patients, the disease is often already disseminated in extramedullary sites, especially in the central nervous system. Still, for young adults, the prognosis has been significantly improved, as proven by the Group of Research on Adult ALL (GRAALL) randomized controlled trial, which explored the role of hyperfractionated cyclophosphamide (hyper-C) dose intensification in newly-diagnosed Philadelphia (Ph)-negative ALL patients on a chemotherapy regimen similar to that of pediatric patients [5]. The complete remission (CR) was $91.9 \%$, and for a median follow-up of 5.2 years, the 5-year event-free survival (EFS) and overall survival (OS) were $52.2 \%$ and $58.5 \%$, respectively. In adolescents and young adults aged 15-20 years, the use of full pediatric protocols is supported by many comparative studies, with long term-survival of almost $70 \%$ [6].

The initial diagnosis of a possible malignancy is determined based on clinical symptoms such as

weight loss, night sweats, fatigue, infections, and bleeding, as well as by altered abnormal laboratory results that indicate anemia or thrombocytopenia. Subsequently, the final diagnosis is based on flow cytometry immunophenotyping that identifies malignant clones positive for cluster of differentiation (CD) 10, CD19, CD20, CD22, CD24, and CD79a. During normal $B$ cell maturation, CD34 is first downregulated together with terminal deoxynucleotidyl transferase (TdT), followed by CD10 and CD38, while CD45 expression is upregulated along with CD21 and CD22 (11244048). Most aberrancies are related to the coexpression/over- or under-expression of CD10, TdT, CD38, CD34, CD20, and cross lineage myeloid expression, while aberrant T-cell antigen expression is less frequent. 
Patients with chromosomal alterations such as hyperploidy or $\dagger(12 ; 21)(p 13 ; q 22)$ have a better prognosis, whereas $+(9 ; 22)(q 34 ; q 11.2)$ or $\dagger(4 ; 1)(q 21 ; q 23)$ translocations are associated with poorer survival rates [710]. In addition, the 2016 WHO classification includes two provisional indicators associated with negative prognosis: B-ALL with intrachromosomal amplification of chromosome 21, and BCR-ABL 1-like B-ALL. The latter is defined by $B C R-A B L 1$ ALL-like alteration of the IKZFI gene without the BCR-ABLI fusion protein. The genomic landscape of BCR-ABL1-like B-ALL suggests that this entity is characterized by alterations in a limited number of pathways, all of which are responsive to inhibition with existing TKIs [10-13].

Conversely, T-cell ALL is less frequent, with immunophenotype analysis that identifies cells positive for CD1, CD2, CD4, CD5, CD8 and CD10. In pediatric patients, the prognosis of T-cell ALL is excellent, exemplified by the 9095\% of cases that achieve complete remission (CR) after chemotherapy. Of great importance for the diagnosis and prognosis of ALL is determination of the presence of theBCR-ABL transcript [10]. Philadelphia-positive $(\mathrm{Ph}+)$ patients, who historically were high risk cases, now benefit from TKIs, with significantly improved prognoses.

Complete remission is generally defined by: fewer than $5 \%$ blasts in the bone marrow; normal maturation of all cellular components in the bone marrow; no extramedullary disease (e.g., CNS, soft tissue disease); ANC (absolute neutrophil count) of at least $1000 / \mu \mathrm{L}$; platelets more than $100,000 / \mu \mathrm{L} ;$ and, lastly, transfusionindependent patients [14]. The detection of residual cells by flow cytometry following therapy is based on asynchronous expression of antigens in comparison with a normal maturation pattern [15], as further discussed later in the manuscript.

\section{Standard Chemotherapy Regimens}

Chemotherapy for ALL is administered in accordance to $\mathrm{Ph}+$ status [16]. First-line chemotherapy for patients under 65 years diagnosed with ALL is the Hoeltzer protocol, which consists of seven steps described in Figure 1 and Table $1,[17,18]$. A valid alternative for therapy is the HyperCVAD protocol, which consists of two treatment cycles repeated four times and an additional maintenance chemotherapy cycle (refer to Figure 2 and Table 2) [19-24]. 
Table 1. First-line therapy protocol for patients under 65 years diagnosed with acute lymphoblastic leukemia (ALL)Hoeltzer Protocol for ALL

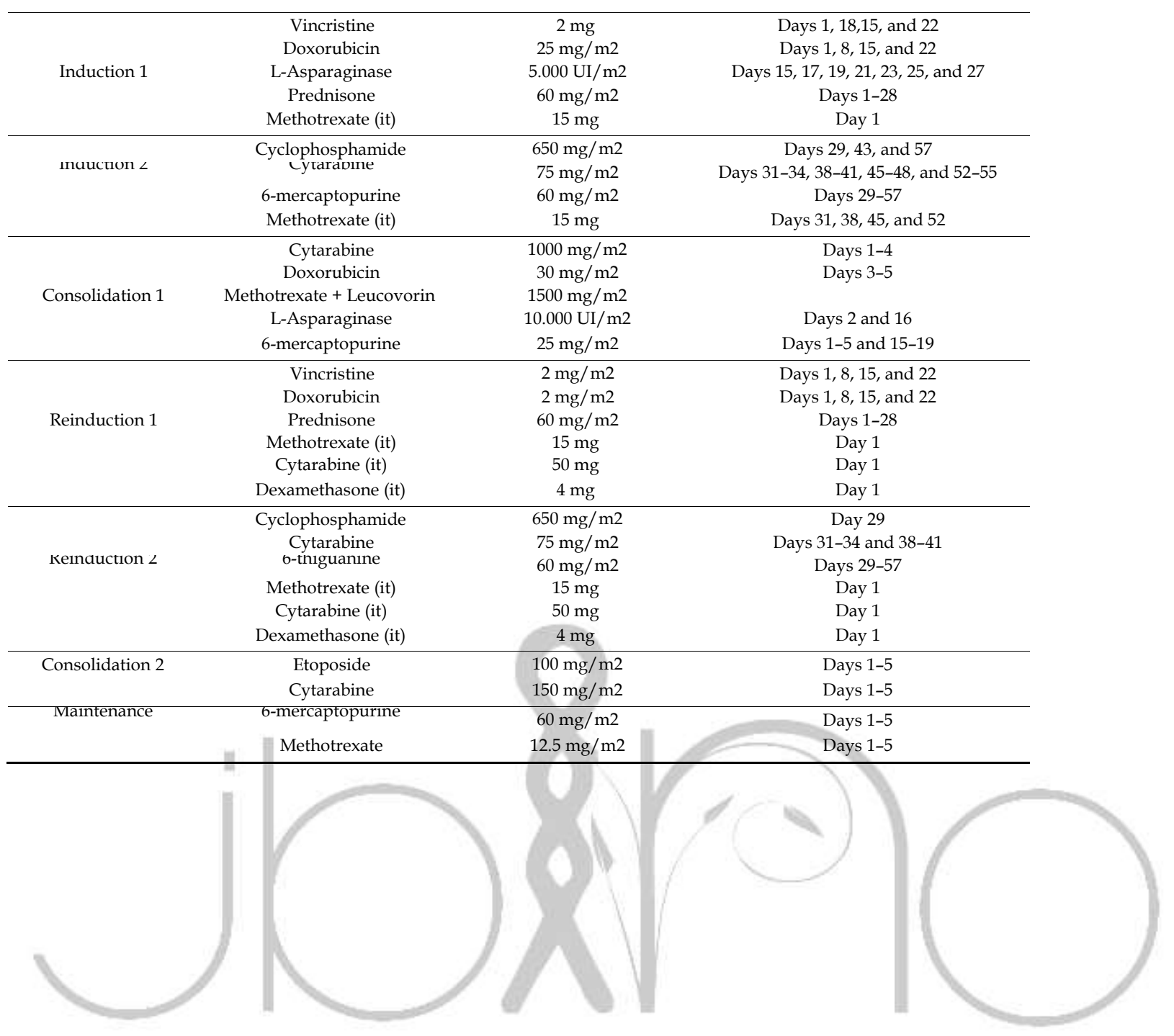




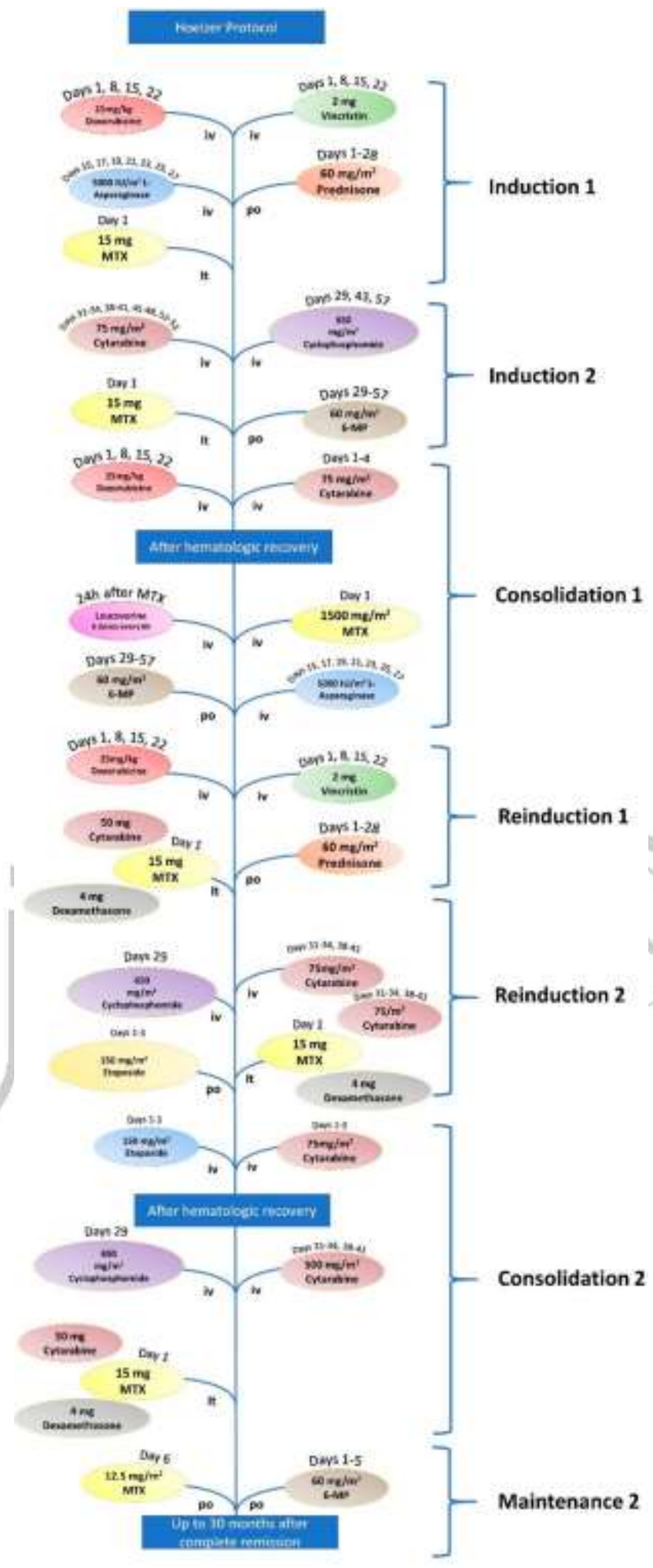

Figure 1. Workflow of the first-line therapy Hoelzer protocol for patients under the age of 65 years diagnosed with B-cell ALL (B-ALL). 


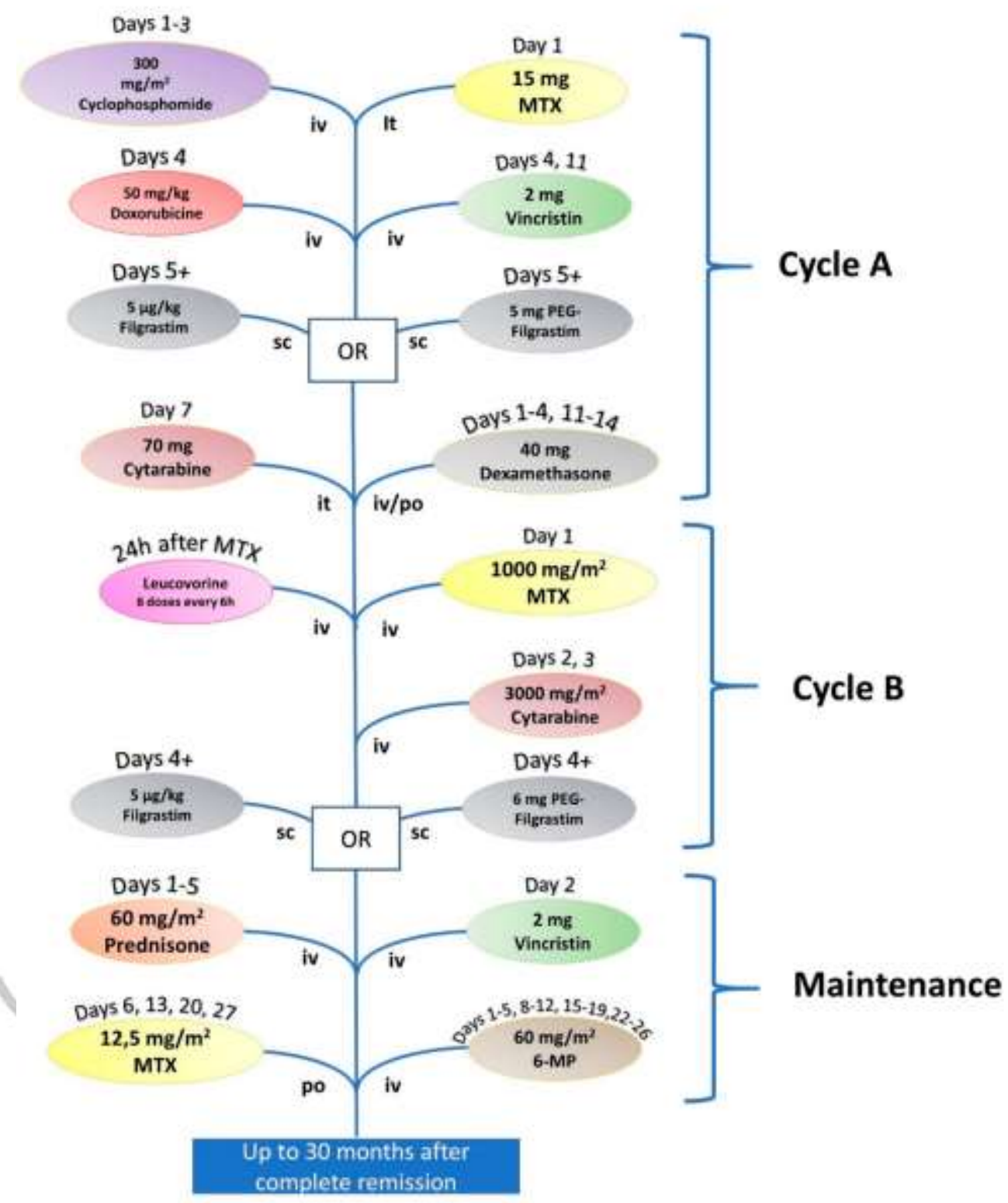

Figure 2. Workflow of the alternative treatment protocol, HyperCVAD, for patients under the age of 65 diagnosed with ALL.

For relapsed ALL patients under 65, the salvage chemotherapy regimen is based on three blocks of administration with methotrexate (MTX), as shown in Figure 3 and Table 3. For T-cell ALLs that relapse after the first cycle of chemotherapy, the protocol includes the administration of $1.5 \mathrm{mg} / \mathrm{m}^{2}$ nelarabine at Days 1,3 , and 5 , a protocol that is repeated six times. Salvage chemotherapy for these patients also includes a high dose of cytarabine $(\mathrm{Cy} t)$ in combination with mitoxantrone protocol that consists of the administration of $3 \mathrm{mg} / \mathrm{m}^{2}$ Cyt at Days $1-5$ plus $80 \mathrm{mg} / \mathrm{m}^{2}$ mitoxantrone at Day $3[25,26]$. $\mathrm{Ph}+\mathrm{ALLS}$ are also treated with a protocol that consists of an induction cycle, two consolidation cycles, and one maintenance cycle, as shown in Figure 4 and Table 4 [27]. This maintenance chemotherapy cycle consists of $600 \mathrm{mg}$ imatinib each day for the remainder of the regimen, as further discussed in the manuscript. 


\section{Salvage Protocol}

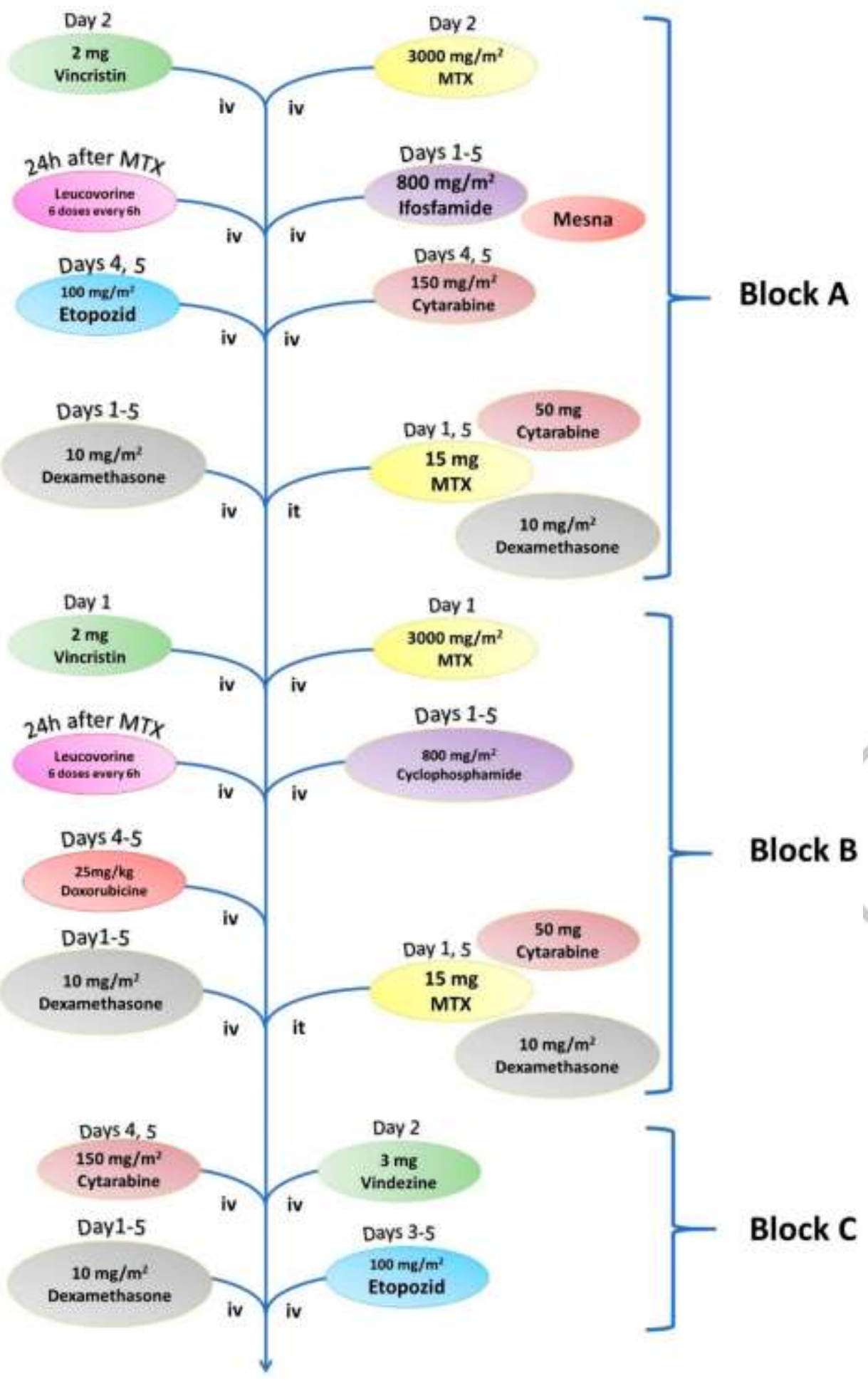

Figure 3. Workflow of the salvage chemotherapy regimen for patients under the age of 65 with relapsing ALL. 
Table 2. HyperCVAD protocol for ALL, an alternative to the Hoelzer protocol for patients under 65 years.HyperCVAD

\begin{tabular}{|c|c|c|c|}
\hline & Eyctophosphannicte & $300 m m^{2} / m^{2}$ & Đays 1, 2, and 3 \\
\hline \multirow{6}{*}{ Cycle A } & Doxorubicin & $50 \mathrm{mg} / \mathrm{m}^{2}$ & Day 4 \\
\hline & Vincristine & $2 \mathrm{mg}$ & Days 4 and 11 \\
\hline & Filgrastim or pegylated Filgrastim & $\begin{array}{l}5 \mu \mathrm{g} / \mathrm{kg} \text { (Filgrastim) or } \\
6 \mathrm{mg} \text { (PEG Filorastim) }\end{array}$ & Starting Day 5 \\
\hline & Dexamethasone & $40 \mathrm{mg}$ & Days $1-4$ and $11-14$ \\
\hline & Cytarabine (it) & $70 \mathrm{mg}$ & Day 7 \\
\hline & Methotrexate (it) & $15 \mathrm{mg}$ & Day 2 \\
\hline \multirow{3}{*}{ Cycle B } & Methotrexate (+Leucovorin) & $1000 \mathrm{mg} / \mathrm{m}^{2}$ & Day 1 \\
\hline & Cytarabine & $6000 \mathrm{mg} / \mathrm{m}^{2}$ & Days 2 and 3 \\
\hline & Filgrastim or PEG Filgrastim & $\begin{array}{c}5 \mu \mathrm{g} / \mathrm{kg} \text { (Filgrastim) or } 6 \\
\mathrm{mg} \text { (PEG Filgrastim) }\end{array}$ & $\begin{array}{l}\text { Starting Day } 4 \text { (Filgrastim) or } \\
\text { at Day } 4 \text { (PEG Filgrastim) }\end{array}$ \\
\hline \multirow{4}{*}{ Maintenance } & Vincristine & $2 \mathrm{mg}$ & Day 2 \\
\hline & Prednisone & $60 \mathrm{mg} / \mathrm{m}^{2}$ & Days $1-5$ \\
\hline & 6-mercaptopurine & $60 \mathrm{mg} / \mathrm{m}^{2}$ & Days $1-5,8-12,15-19$, and $22-26$ \\
\hline & Methotrexate (it) & $12.5 \mathrm{mg} / \mathrm{m}^{2}$ & Days $6,13,20$, and 27 \\
\hline
\end{tabular}

Table 3. For relapsed ALL patients under 65 years of age, the salvage chemotherapy regimen is based on three blocks of administration with methotrexate.Salvage Chemotherapy

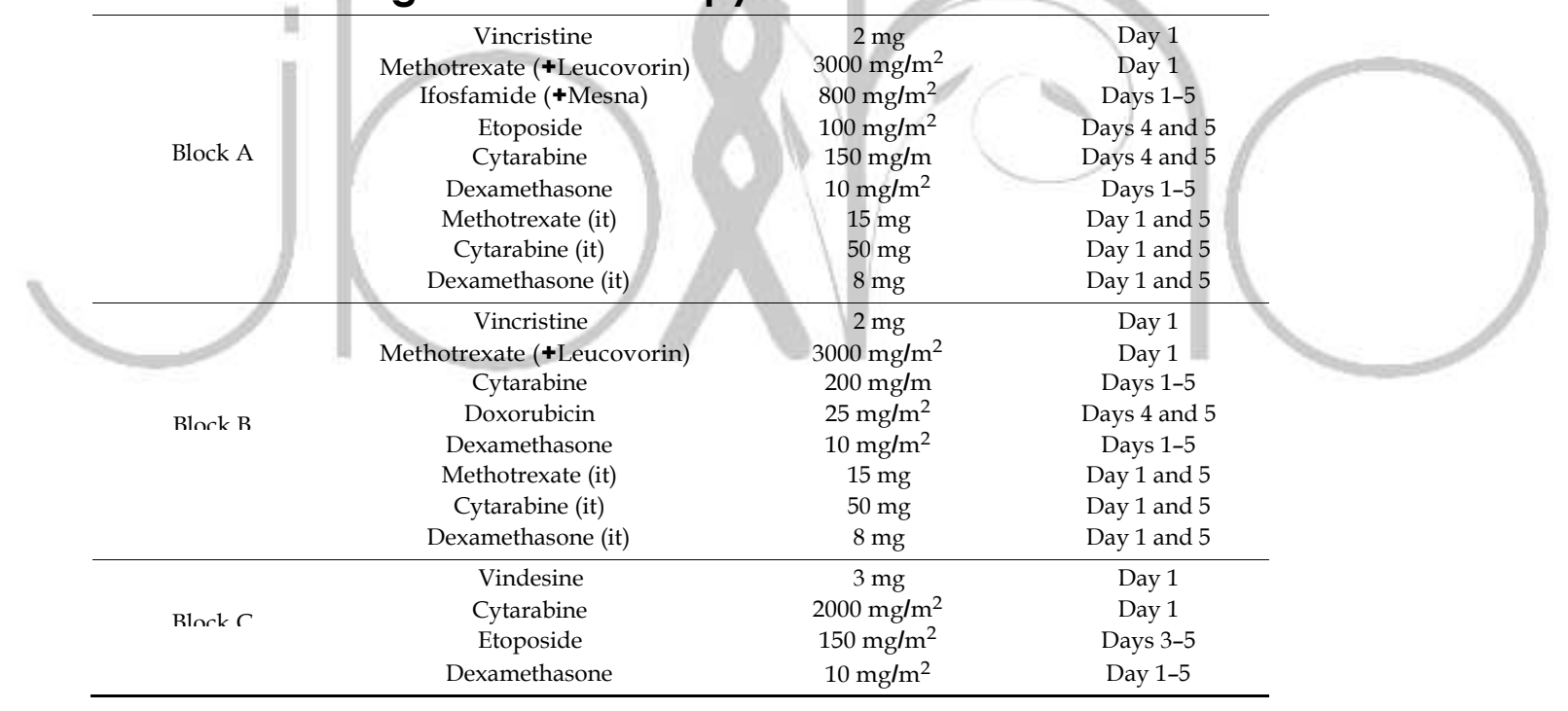


Table 4. Chemotherapy protocol for Ph+ ALL. Philadelphia Positive

ALL

\begin{tabular}{|c|c|c|c|}
\hline \multirow{9}{*}{ Block A } & Vincristine & $2 \mathrm{mg}$ & Day 1 \\
\hline & Methotrexate (+Leucovorin) & $3000 \mathrm{mg} / \mathrm{m}^{2}$ & Day 1 \\
\hline & Ifosfamide (+Mesna) & $800 \mathrm{mg} / \mathrm{m}^{2}$ & Days $1-5$ \\
\hline & Etoposide & $100 \mathrm{mg} / \mathrm{m}^{2}$ & Days 4 and 5 \\
\hline & Cytarabine & $150 \mathrm{mg} / \mathrm{m}$ & Days 4 and 5 \\
\hline & Dexamethasone & $10 \mathrm{mg} / \mathrm{m}^{2}$ & Days 1-5 \\
\hline & Methotrexate (it) & $15 \mathrm{mg}$ & Day 1 and 5 \\
\hline & Cytarabine (it) & $50 \mathrm{mg}$ & Day 1 and 5 \\
\hline & Dexamethasone (it) & $8 \mathrm{mg}$ & Day 1 and 5 \\
\hline \multirow{8}{*}{ Rlock R } & Vincristine & $2 \mathrm{mg}$ & Day 1 \\
\hline & Methotrexate (+Leucovorin) & $3000 \mathrm{mg} / \mathrm{m}^{2}$ & Day 1 \\
\hline & Cytarabine & $200 \mathrm{mg} / \mathrm{m}$ & Days $1-5$ \\
\hline & Doxorubicin & $25 \mathrm{mg} / \mathrm{m}^{2}$ & Days 4 and 5 \\
\hline & Dexamethasone & $10 \mathrm{mg} / \mathrm{m}^{2}$ & Days 1-5 \\
\hline & Methotrexate (it) & $15 \mathrm{mg}$ & Day 1 and 5 \\
\hline & Cytarabine (it) & $50 \mathrm{mg}$ & Day 1 and 5 \\
\hline & Dexamethasone (it) & $8 \mathrm{mg}$ & Day 1 and 5 \\
\hline \multirow{4}{*}{ Rlork $C$} & Vindesine & $3 \mathrm{mg}$ & Day 1 \\
\hline & Cytarabine & $2000 \mathrm{mg} / \mathrm{m}^{2}$ & Day 1 \\
\hline & Etoposide & $150 \mathrm{mg} / \mathrm{m}^{2}$ & Days 3-5 \\
\hline & Dexamethasone & $10 \mathrm{mg} / \mathrm{m}^{2}$ & Day $1-5$ \\
\hline
\end{tabular}




\section{$\mathrm{Ph}+\mathrm{ALL}$}

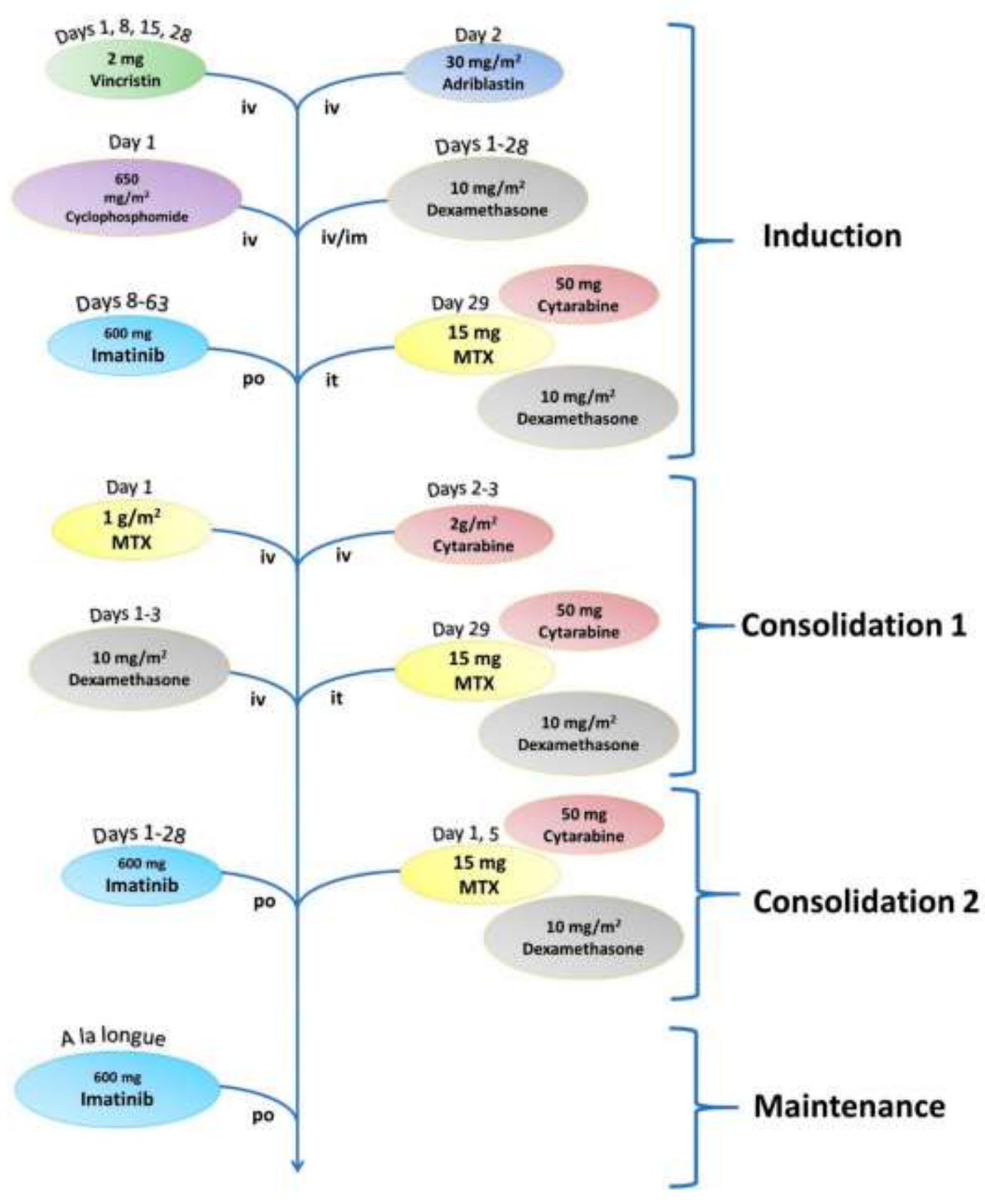

Figure 4. Workflow for the chemotherapy protocol for Philadelphia-positive ALL patients.

An important variable in ALL outcome is age. While adolescents and young adults (from 15/18 to 35/40 years old) are treated with higher intensity and higher cumulative doses of drugs, elderly patients require a less aggressive protocol based on much lower doses of corticosteroids, vincristine and asparaginase, with the avoidance of anthracyclines and alkylating agents to reduce treatment related mortality (TRM). ALL affects many patients worldwide and requires long and rigorous courses of chemotherapy in three stages, with the maintenance phase lasting 2-3 years. While the primary drugs used in the 
maintenance phase, 6-mercaptopurine (6-MP) and methotrexate (MTX), are required to decrease the risk of relapse, they also have potentially serious toxicities, including myelosuppression, which may be life-threatening, as well as gastrointestinal toxicity [28]. Modern therapies, including immunotherapy, have shown good results in the treatment of ALL. Still, cytokine release syndrome (CRS) and neurotoxicity are common toxicities, potentially lifethreatening in severe cases. Risk factors for CRS and neurotoxicity identified so far include disease burden, lymphodepletion intensity, and the chimeric antigen receptor T cells (CART) cell dose administered. Risk-adapted dosing, with lower doses administered to patients with high marrow blast counts, has been successful at decreasing severe CRS rates in this population. Drugs such as tocilizumab and corticosteroids have been effective at ameliorating toxicity, enabling CAR-T cells to be administered safely to many patients without significantly compromising efficacy. A deeper understanding of the pathophysiology underlying CRS and neurotoxicity will enable the development of novel approaches to reduce toxicity and improve outcomes [29-33], as discussed further.

For older and/or frail patients, therapy consists of $1 \mathrm{~g} / \mathrm{kg}$ prednisone for 30 days along with 600-800 mg/day of imatinib, with the latter therapy continued long-term. For patients over 65 years, induction chemotherapy includes the administration of $2 \mathrm{mg}$ vincristine intravenous (i.v.) at Days 1, 8, 15, and
28, plus $25 \mathrm{mg} / \mathrm{m}^{2}$ adriblastine i.v. at Days $1,8,15$, and 28 , plus $8 \mathrm{mg} / \mathrm{m}^{2}$ dexamethasone or $1 \mathrm{mg} / \mathrm{kg}$ prednisone at Days 1-28, plus intrathecal administration of $15 \mathrm{mg}$ methotrexate at Day 1. Maintenance is achieved with purinethol or MTX administration for two years.

In B-ALL, CR is defined as the absence of any symptoms related to the dissemination of blasts into the lymph node or internal organs, and peripheral blood counts of more than 1500 neutrophils/mmc, more than 100,000 platelets, and more than 10 $\mathrm{mg} / \mathrm{dL}$ hemoglobin. The blood smear must display less than $5 \%$ blasts, with neither cytological nor cytogenetic abnormalities. Hematopoietic stem cell transplantation (HSCT) is designated to B-ALL patients in CR after first-line chemotherapy has failed, in line with the ESMO Clinical Practice Guidelines [34]. Patients may undergo HSCT as first-line treatment after the first cycle of chemotherapy if in CR and exhibiting negative prognostic factors. Such prognostic factors include more than 40,000 leukocytes at diagnosis or high-risk genetic abnormalities [35]. Recent protocols use measurable residual disease (MRD) $<0.01 \%$ to define MRD as positive. MRD assessment and cytogenetics are important prognostic factors in all patients treated upfront with chemotherapy, routinely used to risk-stratify cases and make decisions regarding whether to move on to an allogeneic stem cell transplantation (SCT) or immunotherapy [36-39], as seen in Figure 5. 


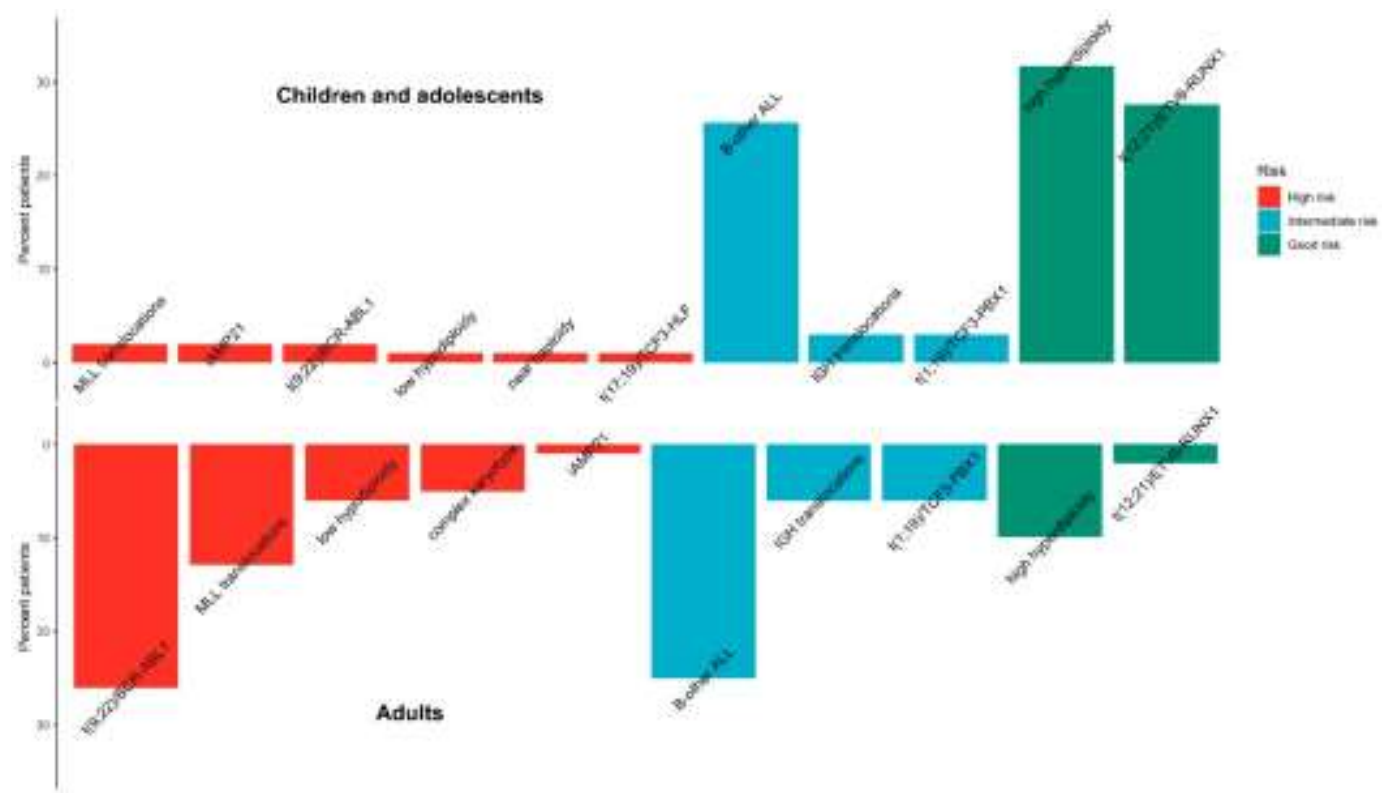

Figure 5. Percent distribution of ALL patients in terms of risk factor and cytogenetic profile.

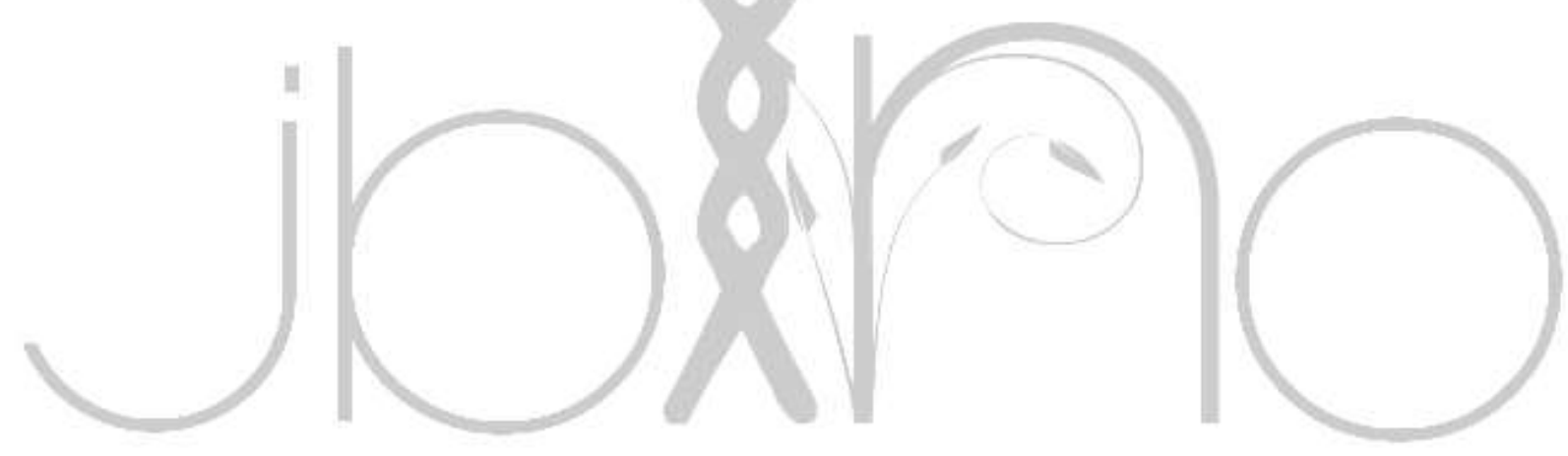




\section{Management of CNS Involvement}

Another important aspect for ALL patients is the involvement of the central nervous system (CNS). Data in support of prophylaxis are limited and most physicians use additional measures $[40,41]$. Thus, lumbar puncture may be carried out, the cerebrospinal fluid investigated, and multiple doses of intrathecal chemotherapy with highdose MTX and/or Cyt administered. Whether high-dose chemotherapy alone is enough to properly prevent CNS prophylaxis, or whether it should be associated with radiotherapy, is a subject of debate. Physicians should consider both the anti-leukemia effects of CNS relapse prophylaxis and the long-term effect on the brain tissue. In Poland, Zaja c-Spychała et al. reported that ALL patients treated with high-dose chemotherapy according to the ALL IC-BFM 2002 trial had cognitive impairment and a decreased volume of selected subcortical structures [42]. Another option is a very high dose of MTX (33.6 $\left.\mathrm{g} / \mathrm{m}^{2}\right)$, which resulted in similar OS to other CNS-directed therapies without the long-term impact on cognitive functions, but with substantial acute toxicities [43]. CNS prophylaxis can be achieved by CNS irradiation, intrathecal MTX in monoor triple therapy (MTX, Cyt and steroids), and systemic high-dose therapy with MTX and/or cytarabine. CNS involvement at diagnosis requires both a standard chemotherapy model and intrathecal chemotherapy until spinal fluid cytology shows blast clearance. Intrathecal therapy consists of MTX $12.5 \mathrm{mg}$, Cyt $50 \mathrm{mg}$, and prednisone $40 \mathrm{mg}$ on Days 1 and 15 of Courses 1, 2, and 8 and on Day 1 of Courses 4, 6, and

maintenance months $2,3,4$, and $5(\times 12)$ [44]. When using very high-dose MTX, Nathan et al. reported

that dose adjustments were needed in 74 of the 88 patient cohort [43]. Out of the 74 patients with dose adjustments, 9 cases had impaired MTX clearance or renal disfunction, 5 had hepatic toxicities, 1 patient had seizures, and 1 had pulmonary toxicity. None of the patients died because of the therapy. Still, this therapy is less toxic than cranial radiation plus intrathecal MTX; the patients treated with very highdose MTX had a stable verbal IQ and increase in performance IQ related to expected practice events over time, in comparison with the group treated with radiotherapy plus intrathecal MTX $[45,46]$. Recurrences within the CNS usually coincide with or predict systemic relapse in the marrow and blood $[47,48]$. Even if adults achieve CR in most cases, relapses are diagnosed in $7 \%$ of cases, especially in the elderly and high-risk populations $[49,50]$. Without prophylactic intrathecal chemotherapy, more than half of adult ALL patients have CNS involvement or relapse [51]. Dara et al. reported that in patients treated with intrathecal chemotherapy following first-line intrathecal chemotherapy with methotrexate (MTX) and corticosteroids, CR was achieved in $76 \%$ of patients. Moreover, $91 \%$ reached CR after second-line intrathecal chemotherapy [52]. Clinical response was documented in $75 \%$ of cases. Although most patients were 
additionally treated with systemic chemotherapy, response rates

did not differ between patients treated with CNS-penetrating and non-CNSpenetrating drugs. CNS progression/relapse occurred in $40 \%$ of patients, with a median progressionfree survival (PFS) of

12.2 months. The median OS was 18.3 months and $55 \%$ of the patients died during follow-up. CNS relapse remains a major problem for the ALL patient [53],

one that will probably be better managed in the near future with the introduction of novel therapies, such as

blinatumomab or CAR-T cells [54-57].

Various risk factors have been associated with CNS involvement in ALL, whether at initial diagnosis or at relapse. CNS involvement has a higher incidence in younger patients. Cerebrospinal fluid (CSF) examination

is the most important laboratory examination, and pathologists associate relapse after initial clearing with increased opening pressure, elevated protein $(>50 \mathrm{mg} / \mathrm{dL}$ ), decreased glucose $(<60 \mathrm{mg} / \mathrm{dL})$, and an increased $W B C$ count $\left(>5 / \mathrm{mm}^{3}\right)$.

These altered parameters are also common in infectious disease, such as in bacterial or viral meningitis. The presence of leukemic cells in the CSF is diagnostic for CNS relapse, a scenario defined as unequivocal morphological evidence of leukemic blasts in the CNS and/or mononuclear cell count $>5 / \mu \mathrm{L}$.

In children, HSCT did not appear to improve outcomes. Thus, Eapen et al.

showed that when comparing 149 patients enrolled on clinical trials to 60 HLA-matched sibling transplanted patients, all treated over a 10-year period, TRM rates were higher following transplantation [58]. The 8-year probabilities of leukemia-free survival were similar after chemotherapy with irradiation and transplantation (66 and $58 \%$, respectively). In the absence of an advantage for one treatment option over another, the data support use of either

intensive chemotherapy with irradiation or HLA-matched sibling transplantation with total body irradiation containing a conditioning regimen for children with ALL in second remission after an isolated CNS relapse.

\section{Tyrosine Kinase Inhibitors for Ph-Positive ALL}

TKls are used in combination with classic chemotherapy for Ph-positive ALL [59-61]. At the University of Texas MD Anderson Cancer Center (MDACC), Jabbour and Kantarjian et al. showed that the combination chemotherapy of hyper-CVAD with ponatinib is efficient in achieving early sustained remissions in Ph-positive ALL [62]. The 2-year eventfree survival rate was $81 \%$. Grade 3 or more toxic effects included infections during induction, reported in $54 \%$ of patients, as well as increased hepatocytolysis in $38 \%$ of patients, thrombotic events in $8 \%$ of cases, myocardial infarction in $8 \%$ of cases, hypertension in $16 \%$ of cases, skin rash in $22 \%$ of cases, and pancreatitis in $16 \%$ of patients. Continuing the investigation, the same MDACC group in Houston showed that when comparing hyper-CVAD plus ponatinib with hyper-CVAD plus dasatinib, the clinical outcome of patients that had received hyper-CVAD plus ponatinib had superior results [63]. The 3-year event-free survival (EFS) for patients 
treated with hyperCVAD plus ponatinib and hyperCVAD plus dasatinib were $69 \%$ and $46 \%$, respectively ( $p=0.04$ ), and the 3 -year OS rates were $83 \%$ and $56 \%$, respectively ( $p=0.03$ ).

The availability of imatinib and of second generation TKIs has improved the outcome of elderly $\mathrm{Ph}+\mathrm{ALL}$ patients. When treated with imatinib, such cases have a better OS in comparison with Ph-negative ALL [64,65]. Advanced age and comorbidities are associated with high TRM. Treatment with a reduced-intensity induction and imatinib yields CR rates with no induction mortality, but with a very high rate of relapse if consolidation is not given [64], resulting in poor OS. With second generation TKIs, lower intensity chemotherapy after induction brings forward similar outcomes as with intensive consolidation, but still poor long-term survival $[66,67]$.

In a randomized trial that compared standard versus lessintensive chemotherapy for newly diagnosed $\mathrm{Ph}+\mathrm{ALL}$ patients, Chalandon et al. showed that less intensive treatment reduced the early mortality without affecting the efficacy, with higher $C R$ rates and an equivalent major molecular response rate (MMR) [68]. MMR is defined as a BCR-ABL1/ABL ratio less than $0.1 \%$ in the $B M$. They analyzed 270 newly diagnosed $\mathrm{Ph}+\mathrm{ALL}$ patients aged 18 to 59. Following the enrolment, patients were randomized to receive imatinib combined with either the less intensive chemotherapy based on vincristine and steroids or the more intense regime with cyclophosphamide, vincristine, doxorubicin, and steroids. In the second course, all patients received similar treatment with MTX, Cyt, and imatinib, followed by HSCT when suitable. The primary endpoint was the assessment of MMR after the second course, which was $66.11 \%$ for the less intensive treatment and $64.5 \%$ for the more aggressive treatment. CR was higher in the first arm (less intensive) in comparison with the second one $198.5 \%$ versus $91 \%$ ). EFS, relapse-free survival, cumulative incidence of relapse, and OS did not differ between arms. The GRAAAL experience of combining imatinib with standard chemotherapy was afterwards confirmed by other subsequent investigators [69-71], with both German and Italian investigators looking at whether intensive chemotherapy during induction might not be as efficient as initially thought, a dilemma still in debate. In the transplant setting, the administration of a TKI does not influence the NRM, but is correlated with an increased frequency of acute graft versus host disease (GVHD) $[72,73]$. Thus, imatinib might be very efficient in the treatment of chronic GVHD, especially when sclerotic and fibrotic features are described. Using TKIs has significantly improved the clinical outcome of Ph+ ALL for the patients that undergo a HSCT, a scenario most likely to improve once novel immunotherapy options are introduced, as is the case of the T-cellengaging bispecific antibody blinatumomab [74].

For Ph-negative ALL, the role of imatinib has yet to be investigated properly in large clinical trials. Still, a link between imatinib-based therapy and the development of a Ph-negative ALL was reported by Cherrier-De Wilde et al. [75]. The describe a case of a 
chronic myeloid leukemia (CML) treated at the first line with imatinib that subsequently developed a Ph-negative $A L L$, suggesting that the leukemic blasts were Ph-negative while residual $\mathrm{Ph}$ positive cells were detected by PCR. Thus, the case described was rather a secondary leukemia and not a blast crisis of CML. Still, the 2019 data do not provide enough proof that might support adding imatinib to Ph-negative ALL.

For R/R T-cell ALL patients, who do not benefit from blinatumomab, alternative salvage therapy

consists of nelarabine, an FDAapproved, T-cell-specific purine nucleoside analogue. Nelarabine is also currently being studied along with $Y$-secretase inhibitors blocking Notch 1 signaling in T-cell ALL. In a phase 2, open-label, multicentric trial, nelarabine was given in an alternateday cycle (Days 1, 3, and 5) at 1.5 $\mathrm{g} / \mathrm{m}^{2} /$ day for R/R T-cell ALL, with a new cycle every 22 days. The results showed a rate of CR rate of $31 \% 195 \%$ $\mathrm{Cl}, 17-48 \%$ ) and 1 -year OS of $28 \%$. The introduction of TKIs into $\mathrm{Ph}+\mathrm{ALL}$ treatment has improved CR rates from $60-70 \%$ to $80-90 \%$ simply by adding imatinib to standard chemotherapy regimens. The optimal usage of TKIs is still being debated: which TKI-based chemotherapy combination is the best, whether using second-generation TKIs (nilotinib, dasatinib) should be preferred over imatinib, or if the standard intensive chemotherapy/TKI combination has any advantage over reduced-dose chemotherapy with TKI.

Ponatinib is a multitargeted TKI [76] with action against Ph-positive lymphoid malignancies [77], especially the cases with $B C R-A B L T 3151$ mutation [78-80]. Ph+ ALL was associated with cure rates of less than $25 \%$ before the TKI era, but present-day therapy leads to long-term survivals for more than $75 \%$ of cases [81]. Ponatinib is very efficient, as proven by the pivotal phase 2 ponatinib $\mathrm{Ph}+\mathrm{ALL}$ and $\mathrm{CML}$ Evaluation (PACE) trial, which evaluated its efficacy at a starting dose of $45 \mathrm{mg}$ once daily in patients resistant/intolerant to dasatinib or nilotinib due to their harboring the BCRABL 1 T315I mutation, with durable and meaningful clinical responses in the heavily pretreated patients [82].

Recent studies have raised several issues regarding allogeneic hematopoietic stem cell transplantation (HSCT): Do HSCT benefits outweigh procedure-related acute mortality and long-term effects in the case of adolescents and young adults? Should minimal residual disease (MRD) be used to determine HSCT or to continue chemotherapy after remission? How should we identify the appropriate type of HSCT and associated conditioning regimens (matched unrelated donor (MUDs), sibling donor, umbilical cord, haploidentical, reduced intensity chemotherapy (RIC)-HSCT)?

\section{Allogeneic Stem Cell Transplantation for ALL}

HSCT should be part of the consolidation therapy for patients with unfavorable molecular profiles. HSCT is part of the consolidation strategy for the ALL patient, as post-remission consolidation strategies include chemotherapy and HSCT [83]. Thus, the management of such cases 
depends on the patient and disease characteristics, especially in the era of novel targeted therapies, such as blinatumomab, inotuzumab, ozogamycin, and CAR-T cells $[54,55,64]$. Novel drugs may provide a bridge to transplant for the ALL patient $[84,85]$ and HSCT is curative for such cases. Nevertheless, the benefit of consolidation chemotherapy remains uncertain in these cases [86]. Thus, when investigating 261 adults with relapsed/refractory (R/R) ALL examined across two phase 2 studies that received blinatumomab in cycles of 4 week continuous infusion and 2 week treatment-free intervals, $56 \%$ achieved CR during the first 2 cycles, compared with $46 \%$ of younger adults.

HSCT in the case of standard-risk adults has a less clearly defined role with the advent of MRD as a prognostic marker capable of easily restratifying patients to high-risk. While in patients with molecularly undetectable leukemia, no proven survival benefit conferred by allo-HSCT was shown when compared to standard chemotherapy, for positive MRD, allogeneic HSCT was linked with an improved relapse-free survival $[87,88]$.

Even if HSCT is curative for an ALL patient in CR1, the benefits of consolidation chemotherapy do not appear to add any significant benefit for patients with available donors who undergo a myeloablative HSCT, as proven by the study coordinated by Weisforf et al. [89]. In 524 adult patients with $A L L$ in CRI who received at least two, one, or no cycles of consolidation before myeloablative HSCT from 2008 to 2012, those receiving at least two, one, or no cycles of consolidation had an adjusted 3-year cumulative incidence of relapse of $20 \%, 27 \%$, and $22 \%$. The 1 year TRM was $16 \%, 18 \%$, and $23 \%$; the adjusted 3-year leukemia-free survival (LFS) was $54 \%, 48 \%$, and $47 \%$; and 3 -year OS was $63 \%, 59 \%$, 
and $54 \%$ Multivariable analysis confirmed that consolidation was not prognostic for LFS. Similarly, consolidation was not associated with OS, relapse, TRM, or GVHD.

In a cooperative prospective study set up in seven countries, very-high-risk $A L L$ in CRI cases were defined by the presence of at least one of the following criteria: (1) failure to achieve $\mathrm{CR}$ after the first four drug induction phase; (2) $t(9 ; 22)$ or $t(4 ; 11)$ clonal abnormalities; and (3) poor response to prednisone associated with $T$ immunophenotype, WBC of $100 \times 109 / \mathrm{L}$ or greater, or both. The primary outcome was disease-free survival, and analysis was by intention to treat. A total of 357 patients entered the study, of whom 280 were assigned chemotherapy and 77 , related-donor HSCT. 5-year disease-free survival was $40.6 \%$ in those treated with chemotherapy and $56.7 \%$ in those assigned transplantation; 5-year survival was $50.1 \%$ and $56.4 \%$. Although the combination of chemotherapy with TKI is considered the standard of care in patients with Ph-positive ALL, little is known about the impact of additional cytogenetic abnormalities (ACAs). Therefore, after retrospectively evaluating 1375 adult patients who underwent their first allogeneic HSCT in the TKI era, Akahoshi et al. reported that 224 patients had ACAs (16.3\%). The ACAs that were seen in more than 20 cases $(1.5 \%)$ were as follows: -7 , del(22), del(9), +8, and $+X$. OS at 4 years was $56.9 \%$ in the group with ACAs and $60.5 \%$ in the group without ACAs. The cumulative incidence of relapse at
4 years was $28.9 \%$ in the group with ACAs and in the group with Ph alone. In multivariate analyses, there were no statistically significant differences in the risk of overall mortality or risk of relapse between the groups with and without ACAs.

A high-risk ALL patient profile is that with disease stage beyond the first CR, as well as that with CRI and poor risk cytogenetics. This includes $t(9 ; 22)$, $t(4 ; 11), t(1 ; 19)$, complex karyotype, and low hypodiploidy. Such a patient profile includes a slow response to induction chemotherapy, defined as more than 4 weeks to obtain $C R$, failure to achieve CR after induction, age over 35 or leukocytosis at diagnosis. Leukocytosis at diagnosis is defined as more than 30 $\times 10^{9} / \mathrm{L}$ in B-precursor ALL or more than $100 \times 10^{9} / \mathrm{L}$ in T-cell ALL. Positive MRD is also associated with a poor outcome, even if the patient may or may not have morphological remission [90-92]. Autologous HSCT is not better than chemotherapy alone for the ALL patient because of its high relapse rate, according to the National Marrow Donor Program and Center for International Blood and Marrow Transplant Research of the National Institutes of Health in the US [93,94]; thus, an allogeneic HSCT is the best available therapy

option for high-risk ALL patients, despite a high transplant-related mortality $[95,96]$. For ALL patients with a standard risk in the first $C R$, an HSCT has yet to prove to be superior to chemotherapy, but the UKALL/XII/Eastern Cooperative Oncology Group (ECOG) 2993 and the Dutch-Belgian Cooperative Trial Group for Hematology Oncology (HOVON)-18 ALL/HOVON-37 ALL studies have shown 
an OS for those that have received HSCT from a matched related donor [97]. Cumulative incidences of relapse at 5 years were, respectively, 24 and $55 \%$ for patients with a donor versus those without a donor. Non-relapse mortality (NRM) was estimated at $16 \%$ $(+/-4)$ at 5 years after allogeneic HSCT. Thus, 5-year DFS was significantly better in the donor group: 60 versus $42 \%$ in the no-donor group. After risk-group analysis, improved outcome was more pronounced in standard-risk patients with a donor, with an OS of $69 \%$ at 5 years. Even if a similar outcome was reported for all leukemia patients when comparing a related with an unrelated HSCT [98-100], the ones with an unrelated donor seemed to have a poorer outcome, as shown by a higher TRM [67].

\section{Immunotherapy for ALL}

Ph-R/R B-cell ALL patients also benefit from blinatumomab, which is an FDA-approved bispecific murine antibody that simultaneously targets CD3 and CD19. The CR rate after blinatumomab is $67 \%$, but the therapy is often associated with CRS (high fever, nausea, headaches), hepatic, and neurological side effects, among others [101-104].

T-cell ALL has an intrinsic resistance to chemotherapy, and thus a poor prognosis. Immunotherapy has the potential to improve the outcome of such patients. As CD38 is expressed in low levels in both normal lymphoid and myeloid cells, it may be an accurate target. Daratumumab is an immunoglobulin Gik monoclonal antibody that binds to CD38, already approved for the therapy of $R / R$ multiple myeloma [105-107]. In Philadelphia, Teachey et al. tested daratumumab in a large panel of T-ALL patient-derived xenografts and found great efficacy in most cases [108]. In Jerusalem, Ganzel et al. further investigated the role of anti-CD38 immunotherapy [109], by treating a 14 year old boy diagnosed with R/R B-ALL. The response was good, with limited toxicity. However, after 6 months, he relapsed again and was administered bortezomib and gemtuzumab ozogamycin. In the post-transplant setting, daratumumab may play a role, as shown by Bonda et al. [110], who successfully saved a 32 year old young man with an early precursor T-ALL, relapsed after a previous allogeneic HSCT. Still, only isolated case reports have been published to date, and more extensive clinical trials are needed before assessing the role of daratumumab for ALL.

The anti-CD20 monoclonal antibody rituximab has had a substantial role in the improvement of outcome in Burkitt leukemia/lymphoma. In the US, Thomas et al., by treating 282 young adults with de novo Ph-negative precursor B-cell ALL with either standard or modified hyper-CVAD regimens, proved that the incorporation of rituximab in the hyperCVAD regimen improves the outcome of CD20-postitive Ph-ALL [1 111$]$. The CR rate was $95 \%$, with 3-year rates of CR duration (CRD) and OS of $60 \%$ and $50 \%$, respectively. In the younger lage < 60 years) CD20-positive subset, rates of CRD and OS were superior with the modified hyper-CVAD and rituximab regimens compared with standard hyper-CVAD (70\% vs. 38\%). In contrast, rates of CRD and OS for CD20-negative 
counterparts treated with modified versus standard hyper-CVAD regimens were similar $(72 \%$ vs. $68 \%$ and $64 \%$ vs. $65 \%)$. Older patients with CD20-positive ALL did not benefit from rituximabbased chemoimmunotherapy (rates of CRD $45 \%$ vs. $50 \%$ and OS $28 \%$ vs. $32 \%$, respectively), related in part to deaths in CR. The data were confirmed in Europe by GRAAL investigators on 206 patients treated between 2006 and 2014 [112]. After a median follow-up of 30 months, EFS was longer in the rituximab group than in the control group (hazard ratio, $0.66 ; 95 \% \mathrm{Cl}, 0.45$ to $0.98 ; p=0.04)$; the estimated 2-year EFS rates were $65 \%$ and $52 \%$, respectively. Treatment with rituximab remained associated with longer EFS in a multivariate analysis. Under investigation is now the use of inotuzumab ozogamycin (InO), a monoclonal antibody anti-CD22, which was studied in adults with $R / R$ ALL $[113,114]$. In the MDACC study coordinated by Kantarjian et al., the median age was 36 years (range 6-80). CD22 was expressed in more than $50 \%$ of blasts in all patients. The median number of courses was two (range 1-5) and the median time between courses was 3 weeks (range 3-6). A total $18 \%$ of patients had CR, 39\% had marrow complete response, $39 \%$ had resistant disease, and $4 \%$ died within 4 weeks of starting treatment. The OS was $57 \%$. The most frequent adverse events during course one of treatment were fever (grade $1-2$ in 20 patients, grade $3-4$ in nine), hypotension (grade $1-2$ in 12 patients, grade 3 in one), and liverrelated toxic effects (bilirubin: grade 1-2 in 12 patients, grade 3 in two; raised aminotransferase concentration: grade $1-2$ in 27 patients, grade 3 in one). Four years later, the same group reported that the rate of $C R$ was significantly higher in the InO group than in the standard-therapy group $180.7 \%$ vs. $29.4 \%)$. Among the patients who had $C R$, a higher percentage in the $\operatorname{lnO}$ group had results below the threshold for MRD $(0.01 \%$ marrow blasts) $(78.4 \%$ vs. $28.1 \%$ ). In the survival analysis, which included all 326 patients, PFS was significantly longer in the $\ln O$ group (median, 5.0 months vs. 1.8 months); the median OS was 7.7 months vs. 6.7 months, and the hazard ratio was 0.77 . In the safety population, the most frequent grade 3 or higher nonhematological adverse events with InO were liver related. Veno-occlusive liver disease of any grade occurred in 15 patients (11\%) who received InO and in $1 \%$ who received standard therapy. The study showed significantly higher rates of CR, PFS, and OS in the InO group vs. standard chemotherapy. Epratuzumab is another CD22 monoclonal antibody that has been studied in R/R ALL and investigated as part of a salvage therapy regimen both as a single-agent and in combination with standard reinduction chemotherapy [7].

For B-cell ALL, breakthroughs in immunotherapy have given new insights into the clinical management of such cases, reporting previously unprecedented CR rates. Immunotherapy is linked to the clinical development of anti-CD20 naked monoclonal antibodies rituximab, ofatumumab, and obinutuzumab; anti-CD19 ADCs SAR3419 and SGNCD19A and anti-CD19 bispecific antibody 
blinatumomab; anti-CD22 naked monoclonal antibody epratuzumab and anti-CD22 ADC inotuzumab ozogamycin; anti-CD52 naked monoclonal antibody alemtuzumab; and anti-CD19 CAR-T cells [115]. By adding rituximab to B-ALL, the chemotherapy protocol has improved the outcomes of younger patients with CD20+ Ph-negative ALL [112]. Maury et al. report that, between 2006 and 2014 , a total of 209 patients were enrolled in a large, multicentric study: 105 in the rituximab group and 104 in the control group. After a median follow-up of 30 months, EFS was longer in the rituximab group than in the control group; the estimated 2-year EFS rates were $65 \%$ and $52 \%$, respectively. Treatment with rituximab remained associated with longer EFS in a multivariate analysis. The overall incidence rate of severe adverse events did not differ significantly between the two groups, but fewer allergic reactions to asparaginase were observed in the rituximab group.

Chimeric antigen receptor-modified (CAR)-T cells are genetically engineered $T$ cells that recognize unprocessed antigens. A B lymphocyte will recognize a native (unprocessed) antigen via surface immunoglobulins and then produce secreted antibodies. A T lymphocyte usually recognizes a processed antigen, usually a peptide, associated with MHC proteins on the surface of antigen-presenting cells [116-119]. The technology of producing CAR-T cells is continuously evolving, with fourth generation CAR-Ts constructed to include a cytokine expressing cassette $[54,55,120,121]$. For CAR-T-cell therapy, the $T$ cells are collected, genetically engineered to express an artificial T cell receptor, and then infused back into the patient.
Methods for gene delivery range from viral vectors to RNA-based methods. The use of viral vectors has the added benefit of resulting in permanent gene expression,

thus perpetuating the antitumor activity throughout the lifetime of the CAR-T cells. For the moment, CD19 targeting CAR-T cells have been approved by FDA for R/R B-cell ALL (tisagenlecleucel) and $R / R$ diffuse large B-cell lymphoma (axicabtagene ciloleucel). The success of CD-19 targeting CAR-T was made possible due to the specific and nearly universal expression of CD19 on Blymphoblasts, making it an ideal target for immunotherapy [122,123]. Recently, CAR-T cell application has been expanded to CD22-positive B-cell ALL, with early preclinical studies showing antitumor activity in in vitro and in vivo models [124,125].

CAR-T cells are expected to bring the next big leap forward in leukemia immunotherapy [126], as two products have been approved in the US for Bcell malignancies. Tisangenlecleucel in a single perfusion has provided durable remission with long-term persistence in both pediatric and young adult patients with $R / R$ B-cell ALL, with transient high-grade toxic effects [127]. In the global study, 75 patients received an infusion of tisagenlecleucel.

Therapies based on CAR-T cells may have a huge potential clinical impact. Still, these new therapeutic alternatives may not be the "golden bullet," as several mechanisms of resistance to therapy have been described. One such mechanism is the downregulation of antigen expression byleukemia cells $[128,129]$. Thus, Oak et al., from Stanford University Medical Center, presented their data on 22 patients treated with axicabtagene 
ciloleucel for B-cell lymphomas at the 2018 Annual Meeting of the American Society of Hematology in San Diego. At Day 28 post-administration of the autologous CAR product, the ORR was 86\%: 10 patients had a complete response, 9 had a partial response, 1 had stable disease, and 2 had progressive disease. Both patients (2 of 2) with progressive disease at Day 28 had either dim or partial CD19 expression prior to CAR-T infusion, but nonetheless demonstrated robust Axicel expansion. One patient with Day 28 stable disease showed no CAR-T cell expansion, despite

intact CD19 expression. Overall, there was no statistical difference in relative or absolute CAR-T cells

in patients who responded versus those who did not at Day 28. At Day 90, out of the 22 patients, 5 patients $(26 \%)$ developed progressive disease, and 4 of 5 underwent repeat biopsy. Of these patients, 2 had complete loss of tumor CD19 and another had downregulation of CD19 with variable expression of other B-cell antigens [130] CAR-T cell expansion was noted in multiple patients, suggesting that there may have been T-cell-intrinsic causes of treatment failure. Further studies are necessary to help identify and predict which patients will benefit from targeted immunotherapy $[131,132]$.

\section{Measurable Residual Disease}

The optimal assessment of ALL therapy is measurable residual disease (MRD) measurement. The detection limit with currently available flow cytometry technology is around 1:100.000 malignant cells identified in mononucleated cells. The first attempts to rigorously measure MRD by flow cytometry were published in the late 80s and early 90s $[133,134]$ on two laser cytometers, followed by polymerase chain reaction (PCR)-based MRD detection. Consequently, studies from the late 90s showed that monitoring MRD during the first months of therapy is a powerful indicator for outcome, regardless of whether it is done by PCRbased methods or by flow cytometry $[135,136]$.

An important role in homogenizing and standardizing the flow-cytometrybased detection of MRD in acute leukemia was proposed by the European BIOMED-1 Concerted Action, which defined protocols for identifying normal subsets of $B, T$, and myeloid cells in bone marrow, the starting point for subsequent studies of the aberrant immunophenotypes involved in ALL. These efforts provided an excellent basis for standardized flow cytometric MRD studies in multicenter international treatment protocols for precursor-B-cell ALL and T-cell ALL patients, first by defining a normal pattern, and second, by establishing pathology-based patterns and optimal reagent combinations [137-154].

Current methods of flow cytometry MRD detection are still under improvement. It is under debate which independent markers or combinations of markers are more reliable. CD58 high expression is specific for B-leukemic blasts and thus, according to Shaver et al., it could lead to a cheaper and more time efficient approach [155].

Next generation sequencing (NGS)based technology comprises all the developments of sequencing technologies, from Sanger sequencing to the actual methods that are used predominantly for research, but also in the clinical setting. The most important advantages of this technique are the possibility of identifying a larger 
spectrum of mutations and assessing different genomes without bias and higher sensitivity, thus allowing the identification of low frequency variants. Nevertheless, one of the major drawbacks of NGS is the large number of data that result from these kinds of experiment, which need storage and analysis by bioinformaticians [156-158].

In the Johns Hopkins study, Borowitz et al. used Ficoll-Hypaque-purified BM samples examined by RT-PCR. The presence of the common translocations E2A-PBXI, TEL-AMLI, BCR-ABL, and MLLAF4 was evaluated. Other MLL gene rearrangements were detected by fluorescence in situ hybridization (FISH) studies using a break-apart probe strategy [159]. In Europe, Conter et al. have used screening by PCR amplification using the BIOMED-1 primer sets for Ig kappa deleting element gene rearrangements, "IGK-Kde (Vk-Kde, intron-Kde), complete and incomplete TCR delta (TCRD; Vd-(Dd)-Jd1, Dd2-Jd1, Vd2-Dd3, Dd2-Dd3), and TCR gamma (TCRG; Vg-Jgl.3/2.3, Vg-Jgl.1/2.1) rearrangements [160].

Recently, NGS has been used for MRD evaluation in ALL, as it evaluated numerous $V$ - (D)-J rearrangements linked to residual disease, but also to the normal immune repertoire of that specific cell [161-164]. Kotrova et al. used an NGS-based method to evaluate MDR in 76 patients with ALL and reported that by using NGS, they could predict more precisely the relapse at Day 33 of treatment than by PCR. By NGS, the clonal heterogeneity of the IgH locus has been evaluated, not possible by PCR or flow cytometry [165]. Furthermore, Pulsipher et al. compared NGS-based MRD with flow cytometry MRD in B-cell ALL patients that underwent HSCT. They showed that NGS-based MRD is superior to flow cytometry in predicting relapse and non-relapse in both pre- and post-HSCT samples [166]. Gawad et al. also used NGS-MRD evaluation of patients before and after HSCT transplant in blood samples, and confirmed its feasibility to evaluate relapse in patients where BM samples are not available [167].

Both flow cytometry and PCR are assays sensitive to MRD analysis, with deep clinical impacts $[168,169]$. Still, Denys et al., by analyzing $363 \mathrm{ALL}$ patients at Days 15, 33 and 78, showed that 6-color flow cytometry significantly improves MRD analysis in ALL, but remains less sensitive than PCR-based MRD evaluation [170]. In clinical practice, this is important, especially following the approval of novel drugs, as is the case of blinatumomab, a drug that targets MRD-positive ALL.Gökbuget et al. showed that patients with MRD-positive B-cell precursor ALL had significantly longer RFS and OS when compared with MRD non-responders after treatment with blinatumomab [171].

Nowadays, MRD is the strongest independent prognostic factor in ALL. It is detected by molecular methods that use leukemia-specific or patientspecific molecular markers (fusion gene transcripts, or immunoglobulin/T-cell receptor (IG/TR) gene rearrangements), as well as by multiparametric flow cytometry. Once MRDbased follow-up becomes more efficient [172-175], so does the effect of novel therapies, as is the case of blinatumomab or CAR-T cells, as presented in the article.

\section{Conclusions}

The introduction of TKIs in the firstline chemotherapy for Ph-positive ALL has improved the clinical outcome for these patients. These patients were 
historically associated with cure rates of less than $25 \%$ in the pre-TKI era, but present-day long-term survival has reached more than $75 \%$ OS with the introduction of the novel approaches: immunotherapy, ponatinib, HSCT, and CAR-T cells. The best method for followUp in ALL is MRD assessment. MRD is the measurement of the residual leukemia cells in patients after treatment. The threshold for MRD negativity is one malignant clone in 100,000 mononucleated cells, evaluated by either PCR or flow cytometry. MRD assessment is extensively employed in studies and clinical trials ranging from small molecules to CAR-T cells due to its significant prognostic and predictive value.

Assessing the role of blinatumomab for the treatment of ALL and its potential to replace allogeneic SCT, moving from 'bridge to transplant' to 'transplant replacement' is the major "hot topic" in ALL research, expected to change the standard-of-care for this disease in the following years, with or without CAR-T cells.

\section{Practice Points}

ALL is classified as B-cell ALL and Tcell ALL, according to the WHO classification, and mixed-lineage ALL is a rare form of ALL with malignant cells displaying both B-cell and T-cell characteristic antigens [1,2]. The flow cytometry diagnosis of ALL is based on cells positive for CD10, CD19, CD20, CD22, CD24, and CD79a. The diagnostic workup is further supported by cytogenetics. Thus, hyperploidy or $t(12 ; 21)(\mathrm{p} 13 ; \mathrm{q} 22)$ is associated with a better prognosis, whereas $\dagger(9 ; 22)(q 34 ; q 11.2), t(1 ; 19)(q 23 ; p 13.3)$ or $t(4 ; 1)(q 21 ; q 23)$ translocations are associated with worse outcomes.
The backbone of chemotherapy regimens consists of systemic cytarabine, cyclophosphamide, methotrexate, and dexamethasone (among others), as well as CNS prophylaxis with intrathecal chemotherapy or irradiation. Tyrosine kinase inhibitors are effective in Phpositive ALL and should be added to the chemotherapy protocol. Allo-HSCT is indicated upfront after the first remission in ALL patients with high-risk genetic abnormalities and in relapsed cases. Still, certain subgroups of relapsed or refractory ALL patients benefit from several recently introduced therapies, including blinatumomab (bispecific anti CD3-CD19), inotuzumab ozogamycin (anti CD22), and CD19targeting CAR-T cells. Present-day disease evaluation and follow-up uses MRD assessment, which is increasingly used in the setting of clinical trials and is currently under translation in the routine clinical practice. The threshold for MRD is set to 1 malignant cell in 100,000 normal mononucleated cells, and it can be assessed with flow cytometry, PCR, or NGS.

\section{Future Directions}

- Clarify the clinical significance of the provisional entities: B-cell ALL with intrachromosomal amplification of chromosome 21, and BCR-ABL 1-like B-cell ALL.

- Clarify the appropriate therapy strategies for adolescents and young adult ALL patients, which fall between the standard categories of pediatric or adult ALL.

- Expand the use of CAR-T cells and assess the use of CAR-T cells as upfront therapy.

- Establish the role of MRD monitoring beyond studies and clinical trials. 
- Set up the best standard-of-care for adolescents and young adults with ALL.

- Set up the best standard-of-care for older adults with ALL.

- Define the best treatment options or Ph-positive ALL in the era of TKIs.

Author Contributions: V.S., V.M., P.T. and S.T. contributed equally to the current manuscript and are all considered cofirst authors.

Funding: V.S. was funded by an internal grant of the Iuliu Hatieganu UniversitySchool of Doctoral Studies (PCD 20192020). C.T. was supported from five ongoing Grants of the Romanian Government: Institutional Development Fund (CNFIS-FDI-2019-0636), Mobility Projects for Researchers MC-2019, a joint Romania-China Bilateral Collaboration Grant 2018-2019 (contract 14/2018), by a National Research Grant awarded for Frontiers Research Projects (PN-III-P4-ID-PCCF2016-112) awarded to the Babes Bolyai University in collaboration with the Ion Chiricuta Oncology Institute Cluj Napoca, as well as by an Institutional Grant nr.29PFE/18.10.2018).

Conflicts of Interest: The authors declare no conflict of interest. The funders had no role in the design of the study; in the collection, analyses, or interpretation of data; in the writing of the manuscript, or in the decision to publish the results.

\section{References}

1. Hunger, S.P.; Mullighan, C.G. Acute Lymphoblastic Leukemia in Children. N. Engl. J. Med. 2015, 373, 1541-1552. [CrossRef] [PubMed]

2. Herold, T.; Baldus, C.D.; Gökbuget, N. Ph-like Acute Lymphoblastic Leukemia in Older Adults. N. Engl. J. Med. 2014, 371, 2235. [CrossRef] [PubMed]

3. Jones, L.; Carol, H.; Evans, K.;
Richmond, J.; Houghton, P.J.; Smith, M.A.; Lock, R.B. A Review of New Agents Evaluated against Pediatric Acute Lymphoblastic Leukemia by the Pediatric Preclinical Testing Program. Leukemia 2016, 30, 21332141. [CrossRef] [PubMed]

4. Cortelazzo, S.; Ferreri, A.; Hoelzer, D.; Ponzoni, M. Lymphoblastic Lymphoma. Crit. Rev. Oncol. Hematol.

2017, 113, 304-317. [CrossRef] [PubMed]

5. Graubert, T.A. A Call to Action for Acute Lymphoblastic Leukemia. N. Engl. J. Med. 2014, 371, 1064-1066. [CrossRef] [PubMed]

6. Roberts, K.G.; Li, Y.; Payne-Turner, D.; Harvey, R.C.; Yang, Y.-L.; Pei, D.; McCastlain, K.; Ding, L.; LU, C.; Song, $G$.; et al. Targetable KinaseActivating Lesions in Ph-like Acute Lymphoblastic Leukemia. N. Engl. J. Med. 2014, 371, 1005-1015. [CrossRef] [PubMed]

7. Terwilliger, T.; Abdul-Hay, M. Acute Lymphoblastic Leukemia: A Comprehensive Review and 2017 Update.

Blood Cancer J. 2017, 7, e577. [CrossRef] [PubMed]

8. Baranger, L.; Cuccuini, W.; Lefebvre, C.; Luquet, I.; Perot, C.; Radford, I.; Lafage-Pochitaloff, M. Cytogenetics in the Management of Children and Adult Acute Lymphoblastic Leukemia (ALL): An Update by the Groupe Francophone de Cytogénétique Hématologique (GFCH). Ann. Biol. Clin. 2016, 74, 547-560. [CrossRef] [PubMed]

9. Burke, M.J. How to Manage Asparaginase Hypersensitivity in Acute Lymphoblastic Leukemia. Future Oncol. 
2014, 10, 2615-2627. [CrossRef]

10. Dhawan, R.; Marks, D.I. Who Should Receive a Transplant for Acute Lymphoblastic Leukaemia? Curr. Hematol. Malig. Rep. 2017, 12, 143152. [CrossRef] [PubMed]

11. Yeoh, A.E.J.; LU, Y.; Chin, W.H.N.; Chiew, E.K.H.; Lim, E.H.; Li, Z.; Kham, S.K.Y.; Chan, Y.H.; Abdullah, W.A.; Lin, H.P.; et al. Intensifying Treatment of Childhood B-Lymphoblastic Leukemia With IKZFI Deletion Reduces Relapse and Improves Overall Survival: Results of MalaysiaSingapore ALL 2010 Study. J. Clin. Oncol. 2018, 36, 2726-2735. [CrossRef] [PubMed]

12. Ofran, Y.; Izraeli, S. BCR-ABL (Ph)-like Acute Leukemia-Pathogenesis, Diagnosis and Therapeutic Options. Blood Rev. 2017, 31, 11-16. [CrossRef] [PubMed]

13. Mullighan, C.G. The Genomic Landscape of Acute Lymphoblastic Leukemia in Children and Young Adults.

Hematology 2014, 2014, 174-180. [CrossRef] [PubMed]

14. Paul, S.; Kantarjian, H.; Jabbour, E.J. Adult Acute Lymphoblastic Leukemia. Mayo Clin. Proc. 2016, 91, 1645-1666. [CrossRef] [PubMed]

15. Wasserman, R.; Li, Y.S.; Shinton, S.A.; Carmack, C.E.; Manser, T.; Wiest, D.L.; Hayakawa, K.; Hardy, R.R. A Novel Mechanism for B Cell Repertoire Maturation Based on Response by $B$ Cell Precursors to Pre-B Receptor Assembly. J. Exp. Med. 1998, 187, 259-264. [CrossRef] [PubMed]

16. Iacobucci, I.; Mullighan, C.G. Genetic Basis of Acute Lymphoblastic Leukemia. J. Clin.
Oncol. 2017, 35, 975-983. [CrossRef] [PubMed]

17. Hoelzer, D.; Thiel, E.; Löffler, $H_{\text {. }}$; Büchner, T.; Ganser, A.; Heil, G.; Koch, P.; Freund, M.; Diedrich, H.; Rühl, H.

Prognostic Factors in a Multicenter Study for Treatment of Acute Lymphoblastic Leukemia in Adults. Blood

$1988,71,123-131$.

18. Kantarjian, H.M.; O'Brien, S.; Smith, T.L.; Cortes, J.; Giles, F.J.; Beran, M.; Pierce, S.; Huh, Y.; Andreeff, M.; Koller, C.; et al. Results of Treatment with Hyper-CVAD, a Dose-Intensive Regimen, in Adult Acute Lymphocytic Leukemia. J. Clin. Oncol. 2000, 18, 547-561. [CrossRef]

19. Schafers, H.; Hamm, M.; Wagner, T. Gianturco Self-Expanding Metallic Stents. Eur. J. Cardio-Thorac. Surg.

1992, 6, 278. [CrossRef]

20. Goldstone, A.H.; Richards, S.M.; Lazarus, H.M.; Tallman, M.S.; Buck, G.; Fielding, A.K.; Burnett, A.K.; Chopra, R.; Wiernik, P.H.; Foroni, L.; ef al. In Adults with Standard-Risk Acute Lymphoblastic Leukemia, the Greatest Benefit Is Achieved from a Matched Sibling Allogeneic Transplantation in First Complete Remission, and an Autologous Transplantation is Less Effective than Conventional

Consolidation/Maintenance

Chemotherapy in All Patients: Final Results of the International ALL Trial (MRC UKALL XII/ECOG E2993). Blood 2008, 111, 1827-1833. [CrossRef]

21. Kamps, W.A.; Bökkerink, J.P.; Hählen, K.; Hermans, J.; Riehm, H.; Gadner, H.; Schrappe, M.; Slater, R.; van den Berg-de Ruiter, E.; Smets, L.A.; et al. Intensive Treatment of Children with Acute Lymphoblastic Leukemia According to ALL-BFM-86 
without Cranial Radiotherapy: Results of Dutch Childhood Leukemia Study Group Protocol ALL-7 (1988-1991). Blood 1999, 94, 1226-1236. [PubMed]

22. Volejnikova, J.; Jarosova, M.; Pospisilova, D.; Novak, Z.; Vrbkova, J.; Hajduch, M.; Mihal, V. Treatment and Prognosis of Childhood Acute Lymphoblastic Leukemia on Protocols ALL-BFM 90, 95 and ALL IC-BFM 2002: A Retrospective Single-Center Study from Olomouc, Czech Republic. Neoplasma 2016, 63, 456-461. [CrossRef] [PubMed]

23. Toft, N.; Birgens, H.; Abrahamsson, J.; Griškevičius, L.; Hallböök, H.; Heyman, M.; Klausen, T.W.; Jónsson, Ó.G.; Palk, K.; Pruunsild, K.; et al. Results of NOPHO ALL2008 Treatment for Patients Aged 1-45 Years with Acute Lymphoblastic Leukemia. Leukemia 2018, 32, 606-615. [CrossRef] [PubMed]

24. Muffly, L.; Lichtensztajn, D.; Shiraz, P.; Abrahão, R.; McNeer, J.; Stock, W.; Keegan, T.; Gomez, S.L. Adoption of Pediatric-Inspired Acute Lymphoblastic Leukemia Regimens by Adult Oncologists Treating Adolescents and Young Adults: A Population-Based Study. Cancer 2017, 123, 122-130. [CrossRef] [PubMed]

25. Oskarsson, T.; Söderhäll, S.; Arvidson, J.; Forestier, E.; Montgomery, S.; Bottai, M.; Lausen, B.; Carlsen, N.; Hellebostad, M.; Lähteenmäki, P.; et al. Relapsed Childhood Acute Lymphoblastic Leukemia in the Nordic Countries: Prognostic Factors, Treatment and Outcome. Haematologica 2016, 101, 68-76. [CrossRef] [PubMed]
26. Liedtke, M.; Dunn, T.; Dinner, S.; Coutré, S.E.; Berube, C.; Gotlib, J.; Patel, S.; Medeiros, B. Salvage Therapy with Mitoxantrone, Etoposide and Cytarabine in Relapsed or Refractory Acute Lymphoblastic Leukemia. Leuk. Res. 2014, 38, 1441-1445. [CrossRef] [PubMed]

27. Yanada, M.; Naoe, T. Imatinib Combined Chemotherapy for Philadelphia Chromosome-Positive Acute Lymphoblastic Leukemia: Major Challenges in Current Practice. Leuk. Lymphoma 2006, 47, 1747-1753. [CrossRef] [PubMed]

28. Rudin, S.; Marable, M.; Huang, R.S. The Promise of Pharmacogenomics in Reducing Toxicity During Acute Lymphoblastic Leukemia Maintenance Treatment. Genomics Proteom. Bioinform. 2017, 15, 82-93. [CrossRef] [PubMed]

29. Le, R.Q.; Li, L.; Yuan, W.; Shord, S.S.; Nie, L.; Habtemariam, B.A.; Przepiorka, D.; Farrell, A.T.; Pazdur, R. FDA Approval Summary: Tocilizumab for Treatment of Chimeric Antigen Receptor T CellInduced Severe or Life-Threatening Cytokine Release Syndrome. Oncologist 2018, 23, 943-947. [CrossRef]

30. Hay, K.A. Cytokine Release Syndrome and Neurotoxicity after CD19 Chimeric Antigen ReceptorModified (CAR-) T Cell Therapy. Br. J. Haematol. 2018, 183, 364-374. [CrossRef]

31. Park, J.H.; Rivière, I.; Gonen, M.; Wang, X.; Sénéchal, B.; Curran, K.J.; Sauter, C.; Wang, Y.; Santomasso, B.; Mead, E.; et al. Long-Term Follow-up of CD19 CAR Therapy in 
Acute Lymphoblastic Leukemia. N. Engl. J. Med. 2018, 378, 449-459. [CrossRef] [PubMed]

32. Neelapu, S.S.; Locke, F.L.; Bartlett, N.L.; Lekakis, L.J.; Miklos, D.B.; Jacobson, C.A.; Braunschweig, I.; Oluwole, O.O.; Siddiqi, T.; Lin, Y.; et al. Axicabtagene Ciloleucel CAR TCell Therapy in Refractory Large BCell Lymphoma. N. Engl. J. Med. 2017, 377, 2531-2544. [CrossRef] [PubMed]

33. Tran, E.; Longo, D.L.; Urba, W.J. A Milestone for CAR T Cells. N. Engl. J. Med. 2017, 377, 2593-2596. [CrossRef] [PubMed]

34. Hoelzer, D.; Bassan, R.; Dombret, H.; Fielding, A.; Ribera, J.M.; Buske, C.; ESMO Guidelines Committee. Acute Lymphoblastic Leukaemia in Adult Patients: ESMO Clinical Practice Guidelines for Diagnosis, Treatment and Follow-Up. Ann. Oncol. 2016, 27, v69-v82. [CrossRef] [PubMed]

35. Pui, C.-H.; Robison, L.L.; Look, A.T. Acute Lymphoblastic Leukaemia. Lancet 2008, 371, 1030-1043. [CrossRef]

36. Aldoss, I.T.; Marcucci, G.; Pullarkat, V. Treatment of Acute Lymphoblastic Leukemia in Adults: Applying Lessons Learned in Children. Oncology 2016, 30, 10801091. [PubMed]

37. Horowitz, N.A.; Akasha, D.; Rowe, J.M. Advances in the Genetics of Acute Lymphoblastic Leukemia in Adults and the Potential Clinical Implications. Expert Rev. Hematol. 2018, 11, 781-791. [CrossRef]

38. Borowitz, M.J.; Wood, B.L.; Devidas, M.; Loh, M.L.; Raetz, E.A.; Salzer, W.L.; Nachman, J.B.; Carroll, A.J.;
Heerema, N.A.; Gastier-Foster, J.M.; et al. Prognostic Significance of Minimal Residual Disease in High Risk B-ALL: A Report from Children's Oncology Group Study AALL0232. Blood 2015, 126, 964-971. [CrossRef]

39. Vijayakrishnan, J.; Kumar, R.; Henrion, M.Y.R.; Moorman, A.V.; Rachakonda, P.S.; Hosen, I.; da Silva Filho, M.I.; Holroyd, A.; Dobbins, S.E.; Koehler, R.; et al. A Genome-Wide Association Study Identifies Risk Loci for Childhood Acute Lymphoblastic Leukemia at 10q26.13 and 12q23.1. Leukemia 2017, 31, 573-579. [CrossRef]

40. Larson, R.A. Managing CNS Disease in Adults with Acute Lymphoblastic Leukemia. Leuk. Lymphoma 2018. 59, 3-13. [CrossRef]

41. Qian, L.; Tomuleasa, C.; Florian, I.-A.; Shen, J.; Florian, I.-S.; Zdrenghea, M.; Dima, D. Advances in the Treatment of Newly Diagnosed Primary Central Nervous System Lymphomas. Blood Res. 2017, 52, 159-166. [CrossRef] [PubMed]

42. Zaja,c-Spychała, O.; Pawlak, M.A.; Karmelita-Katulska, K.; Pilarczyk, J.; Derwich, K.; Wachowiak, J. LongTerm Brain Structural Magnetic Resonance Imaging and Cognitive Functioning in Children Treated for Acute Lymphoblastic Leukemia with High-Dose Methotrexate Chemotherapy Alone or Combined with CNS Radiotherapy at Reduced Total Dose to 12 Gy. Neuroradiology 2017, 59, 147-156. [CrossRef] [PubMed]

43. Nathan, P.C.; Whitcomb, T.; Wolters, P.L.; Steinberg, S.M.; Balis, F.M.; Brouwers, P.; Hunsberger, S.; Feusner, J.; Sather, H.; Miser, J.; et al. Very 
High-Dose Methotrexate 133.6 $\mathrm{g} / \mathrm{m}(2))$ as Central Nervous System Preventive Therapy for Childhood Acute Lymphoblastic Leukemia: Results of National Cancer Institute/Children's Cancer Group Trials CCG-191P, CCG-134P and CCG-144P. Leuk. Lymphoma 2006, 47, 2488-2504. [CrossRef] [PubMed]

44. Gökbuget, N.; Dombret, H.; Ribera, J.-M.; Fielding, A.K.; Advani, A.; Bassan, R.; Chia, V.; Doubek, M.; Giebel, S.; Hoelzer, D.; et al. International Reference Analysis of Outcomes in Adults with B-Precursor Ph-Negative Relapsed/Refractory Acute Lymphoblastic Leukemia. Haematologica 2016, 101, 15241533. [CrossRef] [PubMed]

45. Mulhern, R.K.; Fairclough, D.; Ochs, J. A Prospective Comparison of Neuropsychologic Performance of Children Surviving Leukemia Who Received 18-Gy, 24-Gy, or No Cranial Irradiation. J. Clin. Oncol. 1991, 9, 1348-1356. [CrossRef]

46. Krull, K.R.; Hardy, K.K.; Kahalley, L.S.; Schuitema, I.; Kesler, S.R. Neurocognitive Outcomes and Interventions in Long-Term Survivors of Childhood Cancer. J. Clin. Oncol. 2018, 36, 2181-2189. [CrossRef]

47. Winick, N.; Devidas, M.; Chen, S.; Maloney, K.; Larsen, E.; Mattano, L.; Borowitz, M.J.; Carroll, A.; GastierFoster, J.M.; Heerema, N.A.; et al. Impact of Initial CSF Findings on Outcome Among Patients With National Cancer Institute Standardand High-Risk B-Cell Acute Lymphoblastic Leukemia: A Report From the Children's Oncology Group. J. Clin. Oncol. 2017, 35, 2527-2534. [CrossRef]
48. Münch, $V_{. ;}$Trentin, L.; Herzig, J.; Demir, S.; Seyfried, F.; Kraus, J.M.; Kestler, H.A.; Köhler, R.; Barth, T.F.E.; Te Kronnie, G.; et al. Central Nervous System Involvement in Acute Lymphoblastic Leukemia is Mediated by Vascular Endothelial Growth Factor. Blood 2017, 130 , 643-654. [CrossRef]

49. Gaudichon, J.; Jakobczyk, H.; Debaize, L.; Cousin, E.; Galibert, M.D.; Troadec, M.-B.; Gandemer, V. Mechanisms of Extramedullary Relapse in Acute Lymphoblastic Leukemia: Reconciling Biological Concepts and Clinical Issues. Blood Rev. 2019, 36, 40-56. [CrossRef]

50. Sauter, C.S.; DeFilipp, Z.; Inamoto, Y.; Johnston, L.; Nagler, A.; Savani, B.N.; Carpenter, P.A.; Perales, M.-A. ASBMT Statement on Routine Prophylaxis for Central Nervous System Recurrence of Acute Lymphoblastic Leukemia Following Allogeneic Hematopoietic Cell Transplantation. Biol. Blood Marrow Transplant. 2019, 25, e86-e88. [CrossRef]

51. Gorshein, E.; Kalathil, S.; Gharibo, M. Prolonged Survival of Acute Lymphoblastic Leukemia with Intrathecal Treatments for Isolated Central Nervous System Relapse. Case Rep. Hematol. 2018, 2018, 13. [CrossRef] [PubMed]

52. Dara, A.; Mook, B.B.; Doorduijn, J.K.; van den Bent, M.J.; Dinmohamed, A.G.; Bromberg, J.E.C. Efficacy of Intrathecal Chemotherapy in Patients with Central Nervous System Involvement of Hematological Malignancies: A Retrospective Analysis. J. Neurooncol. 2018, 139, 117-123. 
[CrossRef] [PubMed]

53. Agrawal, A.K.; Aguilar, A.; Feusner, J. Unifying the Diagnosis of Isolated Central Nervous System Relapse in Acute Lymphoblastic Leukaemia Based on Minimal Residual Disease Testing. Br. J. Haematol. 2019, 184, 1026-1027. [CrossRef] [PubMed]

54. Tomuleasa, C.; Fuji, S.; Berce, C.; Onaciu, A.; Chira, S.; Petrushev, B.; Micu, W.-T.; Moisoiv, V.; Osan, C.; Constantinescu, C.; et al. Chimeric Antigen Receptor T-Cells for the Treatment of B-Cell Acute Lymphoblastic Leukemia. Front. Immunol. 2018, 9, 239. [CrossRef] [PubMed]

55. Tat, T.; Li, H.; Constantinescu, C.-S.; Onaciu, A.; Chira, S.; Osan, C.; Pasca, S.; Petrushev, B.; Moisoiu, V.; Micu, W.-T.; et al. Genetically Enhanced T Lymphocytes and the Intensive Care Unit. Oncotarget 2018, 9, 16557-16572. [CrossRef] [PubMed]

56. Ribera, J.-M. Efficacy and Safety of Bispecific T-Cell Engager Blinatumomab and the Potential to Improve

Leukemia-Free Survival in B-Cell Acute Lymphoblastic Leukemia. Expert Rev. Hematol. 2017, 10, 10571067. [CrossRef]

57. Pehlivan, K.C.; Duncan, B.B.; Lee, D.W. CAR-T Cell Therapy for Acute Lymphoblastic Leukemia: Transforming the Treatment of Relapsed and Refractory Disease. Curr. Hematol. Malig. Rep. 2018, 13, 396-406. [CrossRef] [PubMed]

58. Eapen, M.; Zhang, M.-J.; Devidas, M.; Raetz, E.; Barredo, J.C.; Ritchey, A.K.; Godder, K.; Grupp, S.; Lewis, V.A.; Malloy, K.; et al. Outcomes after HLA-Matched

Sibling
Transplantation or Chemotherapy in Children with Acute Lymphoblastic Leukemia in a Second Remission after an Isolated Central Nervous System Relapse: A Collaborative Study of the Children's Oncology Group and the Center for International Blood and Marrow Transplant Research. Leukemia 2008, 22, 281-286. [CrossRef] [PubMed]

59. Hoy, S.M. Ponatinib: A Review of Its Use in Adults with Chronic Myeloid Leukaemia or Philadelphia Chromosome-Positive Acute Lymphoblastic Leukaemia. Drugs 2014, 74, 793-806. [CrossRef]

60. Cortes, J.E.; Kim, D.-W.; Pinilla-lbarz, J.; le Coutre, P.; Paquette, R.; Chuah, C.; Nicolini, F.E.; Apperley, J.F.; Khoury, H.J.; Talpaz, M.; et al. A Phase 2 Trial of Ponatinib in Philadelphia Chromosome-Positive Leukemias. N. Engl. J. Med. 2013, 369, 1783-1796. [CrossRef]

61. Talpaz, M.; Shah, N.P.; Kantarjian, H.; Donato, N.; Nicoll, J.; Paquette, R.; Cortes, J.; O'Brien, S.; Nicaise, C.; Bleickardt, E.; et al. Dasatinib in Imatinib-Resistant Philadelphia Chromosome-Positive Leukemias. N. Engl. J. Med. 2006, 354, 2531-2541. [CrossRef] [PubMed]

62. Jabbour, E.; Kantarjian, H.; Ravandi, F.; Thomas, D.; Huang, X.; Faderl, S.; Pemmaraju, N.; Daver, N.; GarciaManero, G.; Sasaki, K.; et al. Combination of Hyper-CVAD with Ponatinib as First-Line Therapy for Patients with Philadelphia Chromosome-Positive Acute Lymphoblastic Leukaemia: A SingleCentre, Phase 2 Study. Lancet Oncol. 2015, 16, 1547-1555. 


\section{[CrossRef]}

63. Sasaki, K.; Jabbour, E.J.; Ravandi, F.; Short, N.J.; Thomas, D.A.; GarciaManero, G.; Daver, N.G.; Kadia, T.M.; Konopleva, M.Y.; Jain, N.; et al. Hyper-CVAD plus Ponatinib versus Hyper-CVAD plus Dasatinib as Frontline Therapy for Patients with Philadelphia Chromosome-Positive Acute Lymphoblastic Leukemia: A Propensity Score Analysis. Cancer 2016, 122, 3650-3656. [CrossRef] [PubMed]

64. Wieduwilt, M.J. How Should We Treat Older Adults with Ph+ Adult ALL and What Novel Approaches Are

Being Investigated? Best Pract. Res. Clin. Haematol. 2017, 30, 201-211. [CrossRef] [PubMed]

65. Rousselot, P.; Delannoy, A. Optimal Pharmacotherapeutic

Management \# of Acute Lymphoblastic Leukaemia in the Elderly. Drugs Aging 2011, 28, 749764. [CrossRef] [PubMed]

66. Rousselot, P.; Coudé, M.M.; Gokbuget, N.: Gambacorti Passerini, C.; Hayette, S.; Cayuela, J.-M.; Huguet, F.; Leguay, T.; Chevallier, P.; Salanoubat, C.; et al. Dasatinib and Low-Intensity Chemotherapy in Elderly Patients with Philadelphia ChromosomePositive ALL. Blood 2016, 128, 774782. [CrossRef] [PubMed]

67. Fielding, A.K.; Rowe, J.M.; Richards, S.M.; Buck, G.; Moorman, A.V.; Durrant, I.J.; Marks, D.I.; McMillan, A.K.; Litzow, M.R.; Lazarus, H.M.; et al. Prospective Outcome Data on 267 Unselected Adult Patients with Philadelphia Chromosome-positive Acute Lymphoblastic Leukemia Confirms Superiority of Allogeneic
Transplantation

over

Chemotherapy in the Pre-Imatinib Era: Results from the International ALL Trial MRC UKALLXII/ECOG2993. Blood 2009, 113, 4489-4496. [CrossRef]

68. Chalandon, Y.; Thomas, X.; Hayette, S.; Cayuela, J.-M.; Abbal, C.; Huguet, F.; Raffoux, E.; Leguay, T.; Rousselot, P.; Lepretre, S.; et al. Randomized Study of ReducedIntensity Chemotherapy Combined with Imatinib in Adults with PhPositive Acute Lymphoblastic Leukemia. Blood 2015, 125, 37113719. [CrossRef]

69. Ottmann, O.G.; Wassmann, B.; Pfeifer, H.; Giagounidis, A.; Stelljes, M.; Dührsen, U.; Schmalzing, M.; Wunderle, L.; Binckebanck, A.; Hoelzer, D.; et al. Imatinib Compared with Chemotherapy as Front-Line Treatment of Elderly Patients with Philadelphia Chromosome-Positive Acute Lymphoblastic Leukemia (Ph+ALL). Cancer 2007, 109, 2068-2076. [CrossRef]

70. Foà, R.; Vitale, A.; Vignetti, M.; Meloni, G.; Guarini, A.; De Propris, M.S.; Elia, L.; Paoloni, F.; Fazi, P.; Cimino, G.; et al. Dasatinib as FirstLine Treatment for Adult Patients with Philadelphia Chromosome-Positive Acute Lymphoblastic Leukemia. Blood 2011, 118, 6521-6528. [CrossRef]

71. Vignetti, M.; Fazi, P.; Cimino, G.; Martinelli, G.; Di Raimondo, F.; Ferrara, F.; Meloni, G.; Ambrosetti, A.; Quarta, G.; Pagano, L.; et al. Imatinib plus Steroids Induces Complete Remissions and Prolonged Survival in Elderly Philadelphia Chromosome-Positive 
Patients with Acute Lymphoblastic Leukemia without Additional Chemotherapy: Results of the Gruppo Italiano Malattie Ematologiche Dell'Adulto (GIMEMA) LAL0201-B Protocol. Blood 2007, 109, 3676-3678. [CrossRef]

72. Leoni, V.; Biondi, A. Tyrosine Kinase Inhibitors in BCR-ABL Positive Acute Lymphoblastic Leukemia.

Haematologica 2015, 100, 295-299. [CrossRef] [PubMed]

73. Olivieri, A.; Locatelli, F.; Zecca, M.; Sanna, A.; Cimminiello, M.; Raimondi, R.; Gini, G.; Mordini, N.; Balduzzi, A.; Leoni, P.; et al. Imatinib for Refractory Chronic Graft-versusHost Disease with Fibrotic Features. Blood 2009, 114, 709-718. [CrossRef] [PubMed]

74. Topp, M.S.; Kufer, P.; Gökbuget, N.; Goebeler, M.; Klinger, M.; Neumann, S.; Horst, H.-A.; Raff, T.;

Viardot, A.; Schmid, M.; et al. Targeted Therapy with the T-CellEngaging Antibody Blinatumomab of Chemotherapy-Refractory Minimal Residual Disease in BLineage Acute Lymphoblastic Leukemia Patients Results in High Response Rate and Prolonged Leukemia-Free Survival. J. Clin. Oncol. 2011, 29, 2493-2498. [CrossRef] [PubMed]

75. Cherrier-De Wilde, S.; Rack, K.; Vannuffel, P.; Delannoy, A.; Hagemeijer, A. PhiladelphiaNegative Acute

Lymphoblastic Leukemia Developing in a CML Patient in Imatinib Mesylate-Induced Complete Cytogenetic Remission. Leukemia 2003, 17, 2046-2048. [CrossRef]

76. Huang, W.-S.; Metcalf, C.A.;
Sundaramoorthi, R.; Wang, Y.; Zou, D.; Thomas, R.M.; Zhu, X.; Cai, L.; Wen, D.; Liu, S.; et al. Discovery of 3[2-(Imidazo[1,2-b]Pyridazin-3YI)Ethynyl]-4-Methyl-N-\{4-[(4Methylpiperazin- 1-YI)Methyl]-3(Trifluoromethyl)Phenyl\}benzamide (AP24534), a Potent, Orally Active Pan-Inhibitor of Breakpoint Cluster Region-Abelson (BCR-ABL) Kinase Including the T315I Gatekeeper Mutant. J. Med. Chem. 2010, 53, 4701-4719. [CrossRef]

77. Stevenson, M.; Pandor, A.; Hamilton, J.; Stevens, J.; Rowntree, C.; MartynSt James, M.; Rawdin, A.; Wong, R. Ponatinib for Treating Acute Lymphoblastic Leukaemia: An Evidence Review Group Perspective of a NICE Single Technology Appraisal. Pharmacoeconomics 2018, 36, 759768. [CrossRef]

78. Visani, G.; Isidori, A. Resistant Chronic Myeloid Leukemia beyond Tyrosine-Kinase Inhibitor Therapy: Which Role for Omacetaxine? Expert Opin. Pharmacother. 2014, 15, 1-3. [CrossRef]

79. Tomuleasa, C.; Dima, D.; Frinc, I.; Patiu, M.; Petrushev, B.; Cucuianu, A.; Berindan-Neagoe, I. BCR-ABL1 T315l Mutation, a Negative Prognostic Factor for the Terminal Phase of Chronic Myelogenous Leukemia Treated with First- and Second-Line Tyrosine Kinase Inhibitors, Might Be an Indicator of Allogeneic Stem Cell Transplant as the Treatment of Choice. Leuk. Lymphoma 2015, 56, 546-547. [CrossRef] [PubMed]

80. Nicolini, F.E.; Basak, G.W.; Kim, D.-W.; Olavarria, E.; Pinilla-lbarz, J.; 
Apperley, J.F.; Hughes, T.; Niederwieser, D.; Mauro, M.J.; Chuah, C; i et al. Overall Survival with Ponatinib versus Allogeneic Stem Cell Transplantation in Philadelphia Chromosome-Positive Leukemias with the T315l Mutation. Cancer 2017, 123, 2875-2880. [CrossRef]

81. Short, N.J.; Kantarjian, H.; Pui, C.-H.; Goldstone, A.; Jabbour, E. SOHO State of the Art Update and Next Questions: Philadelphia Chromosome-Positive Acute Lymphoblastic Leukemia. Clin. Lymphoma Myeloma Leuk. 2018, 18, 439-446. [CrossRef] [PubMed]

82. Cortes, J.E.; Kim, D.-W.; Pinilla-lbarz, J.; le Coutre, P.D.; Paquette, R.; Chuah, C.; Nicolini, F.E.; Apperley, J.F.; Khoury, H.J.; Talpaz, M.; et al. Ponatinib Efficacy and Safety in Philadelphia Chromosome-Positive Leukemia: Final 5-Year Results of the Phase 2 PACE Trial. Blood 2018, 132 , 393-404. [CrossRef]

83. El Fakih, R.; Ahmed, S.; Alfraih, F.; Hanbali, A. Hematopoietic Cell Transplantation for Acute Lymphoblastic Leukemia in Adult Patients. Hematol. Oncol. Stem Cell Ther. 2017, 10, 252-258. [CrossRef] [PubMed]

84. El Fakih, R.; Kharfan-Dabaja, M.A.; Aljurf, M. Refining the Role of Hematopoietic Cell Transplantation for Acute Lymphoblastic Leukemia as Novel Therapies Emerge. Biol. Blood Marrow Transplant. 2016, 22 , 2126-2133. [CrossRef]

85. Gökbuget, N. Treatment of Older Patients with Acute Lymphoblastic Leukemia. Hematol. Am. Soc. Hematol. Educ. Progr. 2016, 2016,
573-579. [CrossRef]

86. Kantarjian, H.M.; Stein, A.S.; Bargou, R.C.; Grande Garcia, C.; Larson, R.A.; Stelljes, M.; Gökbuget, N.; Zugmaier, G.; Benjamin, J.E.; Zhang, A.; et al. Blinatumomab Treatment of Older Adults with Relapsed/Refractory B-Precursor Acute Lymphoblastic Leukemia: Results from 2 Phase 2 Studies. Cancer 2016, 122, 2178-2185. [CrossRef]

87. Leonard, J.T.; Hayes-Lattin, B. Reduced Intensity Conditioning Allogeneic Hematopoietic Stem Cell Transplantation for Acute Lymphoblastic Leukemia; Current Evidence, and Improving Outcomes Going Forward. Curr. Hematol. Malig. Rep. 2018, 13, 329340. [CrossRef] [PubMed]

88. Akahoshi, Y.; Mizuta, S.; Shimizu, H.; Uchida, N.; Fukuda, T.; Kanamori, H.; Onizuka, M.; Ozawa, Y.; Ohashi, K.; Ohta, S.; et al. Additional Cytogenetic Abnormalities with Philadelphia Chromosome-Positive Acute Lymphoblastic Leukemia on Allogeneic Stem Cell Transplantation in the Tyrosine Kinase Inhibitor Era. Biol. Blood Marrow Transplant. 2018, 24, 20092016. [CrossRef] [PubMed]

89. Bejanyan, N.; Zhang, M.-J.; Wang, H.-L.; Lazaryan, A.; de Lima, M.; Marks, D.I.; Sandmaier, B.M.; Bachanova, V.; Rowe, J.; Tallman, M.; et al. Pretransplant Consolidation Is Not Beneficial for Adults with ALL Undergoing Myeloablative Allogeneic Transplantation. Biol. Blood Marrow Transplant. 2018, 24, 945-955. [CrossRef] [PubMed] 
90. Mortuza, F.Y.; Papaioannou, M.; Moreira, I.M.; Coyle, L.A.; Gameiro, P.; Gandini, D.; Prentice, H.G.; Goldstone, A.; Hoffbrand, A.V.; Foroni, L. Minimal Residual Disease Tests Provide an Independent Predictor of Clinical Outcome in Adult Acute Lymphoblastic Leukemia. J. Clin. Oncol. 2002, 20, 1094-1 104. [CrossRef] [PubMed]

91. Brüggemann, M.; Raff, T.; Flohr, T.; Gökbuget, N.; Nakao, M.; Droese, J.; Lüschen, S.; Pott, C.; Ritgen, M.; Scheuring, U.; et al. Clinical Significance of Minimal Residual Disease Quantification in Adult Patients with Standard-Risk Acute Lymphoblastic Leukemia. Blood 2006, 107, 1116-1123. [CrossRef] [PubMed]

92. Bassan, R.; Spinelli, O.; Oldani, E.; Intermesoli, T.; Tosi, M.; Peruta, B.; Rossi, G.; Borlenghi, E.; Pogliani, E.M.; Terruzzi, E.; et al. Improved Risk Classification for Risk-Specific Therapy Based on the Molecular Study of Minimal Residual Disease (MRD) in Adult Acute Lymphoblastic Leukemia (ALL). Blood 2009, 113, 4153-4162. [CrossRef] [PubMed]

93. Bishop, M.R.; Logan, B.R.; Gandham, S.; Bolwell, B.J.; Cahn, J.Y.; Lazarus, H.M.; Litzow, M.R.; Marks, D.I.; Wiernik, P.H.; McCarthy, P.L.; et al. Long-Term Outcomes of Adults with Acute Lymphoblastic Leukemia after Autologous or Unrelated Donor Bone Marrow Transplantation: A Comparative Analysis by the National Marrow Donor Program and Center for International Blood and Marrow Transplant Research. Bone Marrow Transplant. 2008, 41, 635-642.

\section{[CrossRef] [PubMed]}

94. Hallböök, $H_{\text {.; }}$ Hägglund, $H_{\text {.; }}$ Stockelberg, D.; Nilsson, P.-G.; Karlsson, K.; Björkholm, M.; Linderholm, M.; Wahlin, A.; Linder, O.; Smedmyr, B.; et al. Autologous and Allogeneic Stem Cell Transplantation in Adult ALL: The Swedish Adult ALL Group Experience. Bone Marrow Transplant. 2005, 35, 1141-1148. [CrossRef]

95. Hunault, M.; Harousseau, J.-L.; Delain, M.; Truchan-Graczyk, M.; Cahn, J.-Y.; Witz, F.; Lamy, T.; Pignon, B.; Jovet, J.-P.; Garidi, R.; et al. Better Outcome of Adult Acute Lymphoblastic Leukemia after Early Genoidentical Allogeneic Bone Marrow Transplantation (BMT) than after Late High-Dose Therapy and Autologous BMT: A GOELAMS Trial. Blood 2004, 104, 3028-3037. [CrossRef]

96. Marks, D.I.; Aversa, F.; Lazarus, H.M. Alternative Donor Transplants for Adult Acute Lymphoblastic Leukaemia: A Comparison of the Three Major Options. Bone Marrow Transplant. 2006, 38, 467-475. [CrossRef]

97. Cornelissen, J.J.; van der Holt, B.; Verhoef, G.E.G.; van't Veer, M.B.; van Oers, M.H.J.; Schouten, H.C.; Ossenkoppele, G.; Sonneveld, P.; Maertens, J.; van Marwijk Kooy, M.; et al. Myeloablative Allogeneic versus Autologous Stem Cell Transplantation in Adult Patients with Acute Lymphoblastic Leukemia in First Remission: A Prospective Sibling Donor versus No-Donor Comparison. Blood 2009, 113, 1375- 
1382. [CrossRef]

98.

Schwerdtfeger, R.; Hertenstein, B.;

Remberger, M.; Kroeger, N.; Stelljes, M.; Bornhaeuser, M.; Martin, H.; Scheid, C.; et al. Outcome of Allogeneic Hematopoietic Stem-Cell Transplantation in Adult Patients with Acute Lymphoblastic Leukemia: No Difference in Related Compared with Unrelated Transplant in First Complete Remission. J. Clin. Oncol. 2004, 22 , 2816-2825. [CrossRef]

99. Dahlke, J.; Kröger, N.; Zabelina, T.; Ayuk, F.; Fehse, N.; Wolschke, C.; Waschke, O.; Schieder, H.; Renges, H.; Krüger, W.; et al. Comparable Results in Patients with Acute Lymphoblastic Leukemia after Related and Unrelated Stem Cell Transplantation. Bone Marrow Transplant. 2006, 37, 155-163. [CrossRef]

100. Nishiwaki, S.; Miyamura, K.; Ohashi, K.; Kurokawa, M.; Taniguchi, S.; Fukuda, T.; Ikegame, K.; Takahashi, S.; Mori, T.; Imai, K.; et al. Impact of a Donor Source on Adult Philadelphia ChromosomeNegative Acute Lymphoblastic Leukemia: A Retrospective Analysis from the Adult Acute Lymphoblastic Leukemia Working Group of the Japan Society for Hematopoietic Cell Transplantation. Ann. Oncol. Off. J. Eur. Soc. Med. Oncol. 2013, 24, 1594-1602. [CrossRef]

101. Friberg, G.; Reese, D. Blinatumomab (Blincyto): Lessons Learned from the Bispecific t-Cell Engager (BiTE) in Acute Lymphocytic Leukemia (ALL). Ann. Oncol. 2017, 28, 20092012. [CrossRef] [PubMed]
102. Fitzgerald, J.C.; Weiss, S.L.; Maude, S.L.; Barrett, D.M.; Lacey, S.F.; Melenhorst, J.J.; Shaw, P.; Berg, R.A.; June, C.H.; Porter, D.L.; et al. Cytokine Release Syndrome After Chimeric Antigen Receptor T Cell Therapy for Acute Lymphoblastic Leukemia. Crit. Care Med. 2017, 45, e124-e131. [CrossRef] [PubMed]

103. Nagy-Simon, T.; Tatar, A.-S.; Craciun, A.-M.; Vulpoi, A.; Jurj, M.-A.; Florea, A.; Tomuleasa, C.; BerindanNeagoe, I.; Astilean, S.; Boca, S. Antibody Conjugated, Raman Tagged Hollow Gold-Silver Nanospheres for Specific Targeting and Multimodal DarkField/SERS/Two Photon-FLIM Imaging of CD19(+) B Lymphoblasts. ACS Appl. Mater. Interfaces 2017, 9, 21155-21168. [CrossRef] [PubMed]

104. Tatar, A.-S.; Nagy-Simon, T.; Tomuleasa, C.; Boca, S.; Astilean, S. Nanomedicine Approaches in Acute Lymphoblastic Leukemia. J. Control. Release 2016, 238, 123-138. [CrossRef] [PubMed]

105. Dimopoulos, M.A.; Oriol, A.; Nahi, H.; San-Miguel, J.; Bahlis, N.J.; Usmani, S.Z.; Rabin, N.; Orlowski, R.z.; Komarnicki, M.; Suzuki, K.; et al. Daratumumab, Lenalidomide, and Dexamethasone for Multiple Myeloma. N. Engl. J. Med. 2016, 375, 1319-1331. [CrossRef] [PubMed]

106. Palumbo, A.; Chanan-Khan, A.; Weisel, K.; Nooka, A.K.; Masszi, T.; Beksac, M.; Spicka, I.; Hungria, V.; Munder, M.; Mateos, M. V; et al. Daratumumab, Bortezomib, and Dexamethasone for Multiple Myeloma.

N. Engl. J. Med. 2016, 375, 754-766. [CrossRef] [PubMed] 
107. Romero,

D. Haematological Cancer: Improvements with Daratumumab. Nat. Rev. Clin. Oncol. 2016, 13, 592. [CrossRef] [PubMed]

108. Bride, K.L.; Vincent, T.L.; Im, S.-Y.; Aplenc, R.; Barrett, D.M.; Carroll, W.L.; Carson, R.; Dai, Y.; Devidas, M.; Dunsmore, K.P.; et al. Preclinical Efficacy of Daratumumab in T-Cell Acute Lymphoblastic Leukemia. Blood 2018, 131, 995-999. [CrossRef] [PubMed]

109. Ganzel, C.; Kharit, M.; Duksin, C.; Rowe, J.M. Daratumumab for Relapsed/Refractory PhiladelphiaPositive Acute Lymphoblastic Leukemia. Haematologica 2018, 103, e489-e490. [CrossRef]

110. Bonda, A.; Punatar, S.; Gokarn, A.; Mohite, A.; Shanmugam, K.; Nayak, L.; Bopanna, M.; Cheriyalinkal Parambil, B.; Khattry, N. Daratumumab at the Frontiers of Post-Transplant Refractory T-Acute Lymphoblastic Leukemia-a Worthwhile Strategy? Bone Marrow Transplant. 2018, 53, 1487-1489. [CrossRef] [PubMed]

111. Thomas, D.A.; O'Brien, S.; Faderl, S.; Garcia-Manero, G.; Ferrajoli, A.; Wierda, W.; Ravandi, F.; Verstovsek, S.; Jorgensen, J.L.; Bueso-Ramos, C.; et al. Chemoimmunotherapy with a Modified Hyper-CVAD and Rituximab Regimen Improves Outcome in de Novo Philadelphia Chromosome-Negative Precursor BLineage Acute Lymphoblastic Leukemia. J. Clin. Oncol. 2010, 28, 3880-3889. [CrossRef] [PubMed]

112. Maury, S.; Chevret, S.; Thomas, X.; Heim, D.; Leguay, T.; Huguet, F.; Chevallier, P.; Hunault, M.; Boissel,
N.; Escoffre-Barbe, M.; et al. Rituximab in B-Lineage Adult Acute Lymphoblastic Leukemia. N. Engl. J. Med. 2016, 375, 1044-1053. [CrossRef] [PubMed]

113. Kantarjian, $H_{\text {.; }}$ Thomas, D.; Jorgensen, J.; Jabbour, E.; Kebriaei, P.; Rytting, M.; York, S.; Ravandi, F.; Kwari, M.; Faderl, S.; et al. Inotuzumab Ozogamicin, an AntiCD22-Calecheamicin Conjugate, for Refractory and Relapsed Acute Lymphocytic Leukaemia: A Phase 2 Study. Lancet. Oncol. 2012, 13, 403411. [CrossRef]

114. Kantarjian, H.M.; DeAngelo, D.J.; Stelljes, M.; Martinelli, G.; Liedtke, M.; Stock, W.; Gökbuget, N.; O'Brien, S.; Wang, K.; Wang, T.; et al. Inotuzumab Ozogamicin versus Standard Therapy for Acute Lymphoblastic Leukemia. N. Engl. J. Med. 2016, 375, 740-753. [CrossRef] [PubMed]

115. Wei, G.; Wang, J.; Huang, H.; Zhao, Y. Novel Immunotherapies for Adult Patients with B-Lineage Acute Lymphoblastic Leukemia. J. Hematol. Oncol. 2017, 10, 150. [CrossRef] [PubMed]

116. Bennink, J.R.; Doherty, P.C. Different Rules Govern Help for Cytotoxic T Cells and B Cells. Nature 1978, 276 , 829-831. [CrossRef] [PubMed]

117. Carrelha, J.; Meng, Y.; Kettyle, L.M.; Luis, T.C.; Norfo, R.; Alcolea, V.; Boukarabila, H.; Grasso, $\quad F_{\text {.; }}$; Gambardella, A.; Grover, A.; et al. Hierarchically Related LineageRestricted Fates of Multipotent Haematopoietic Stem Cells. Nature 2018, 554, 106-111. [CrossRef]

118. Zinkernagel, R.M. On 'Reactivity' versus 'Tolerance'. Immunol. Cell Biol. 2004, 82, 343-352. [CrossRef] 
119. Kündig, T.M.; Bachmann, M.F.; Ohashi, P.S.; Pircher, H.; Hengartner, H.; Zinkernagel, R.M. On T Cell Memory: Arguments for Antigen Dependence. Immunol. Rev. 1996, 150, 63-90. [CrossRef]

120. Dai, H.; Wang, Y.; LU, X.; Han, W. Chimeric Antigen Receptors Modified T-Cells for Cancer Therapy. J. Natl. Cancer Inst. 2016, 108. [CrossRef]

121. Tvedt, T.H.A.; Ersvaer, E.; Tveita, A.A.; Bruserud, $\varnothing$. Interleukin-6 in Allogeneic Stem Cell Transplantation: Its Possible Importance for Immunoregulation and As a Therapeutic Target. Front. Immunol. 2017, 8, 667. [CrossRef]

122. Wei, G.; Ding, L.; Wang, J.; HU, Y.; Huang, $H$. Advances of CD19Directed Chimeric Antigen Receptor-Modified $T$ Cells in Refractory/Relapsed Acute Lymphoblastic Leukemia. Exp. Hematol. Oncol. 2017, 6, 10. [CrossRef] [PubMed]

123. Luskin, M.R.; DeAngelo, D.J. Chimeric Antigen Receptor Therapy in Acute Lymphoblastic Leukemia Clinical Practice. Curr. Hematol. Malig. Rep. 2017, 12, 370-379. [CrossRef] [PubMed]

124. Haso, W.; Lee, D.W.; Shah, N.N.; Stetler-Stevenson, M.; Yuan, C.M.; Pastan, I.H.; Dimitrov, D.S.; Morgan, R.A.; FitzGerald, D.J.; Barrett, D.M.; et al. Anti-CD22-Chimeric Antigen Receptors Targeting B-Cell Precursor Acute Lymphoblastic Leukemia. Blood 2013, 121, 1165-1174. [CrossRef] [PubMed]

125. Curran, K.J.; Pegram, H.J.; Brentjens, R.J. Chimeric Antigen Receptors for $\mathrm{T}$ Cell Immunotherapy: Current
Understanding and Future Directions. J. Gene Med. 2012, 14, 405-415. [CrossRef] [PubMed]

126. Ledford, H. Engineered Cell Therapy for Cancer Gets Thumbs up from FDA Advisers. Nature 2017, 547, 270. [CrossRef] [PubMed]

127. Maude, S.L.; Laetsch, T.W.; Buechner, J.; Rives, S.; Boyer, M.; Bittencourt, H.; Bader, P.; Verneris, M.R.; Stefanski, H.E.; Myers, G.D.; et al. Tisagenlecleucel in Children and Young Adults with B-Cell Lymphoblastic Leukemia. N. Engl. J. Med. 2018, 378, 439-448. [CrossRef]

128. Han, C.; Sim, S.-J.; Kim, S.-H.; Singh, R.; Hwang, S.; Kim, Y.I.; Park, S.H.; Kim, K.H.; Lee, D.G.; Oh, H.S.; et al. Desensitized Chimeric Antigen Receptor $T$ Cells Selectively Recognize Target Cells with Enhanced Antigen Expression. Nat. Commun. 2018, 9, 468. [CrossRef]

129. Shah, N.N.; Maatman, T.; Hari, P.; Johnson, B. Multi Targeted CAR-T Cell Therapies for B-Cell Malignancies. Front. Oncol. 2019, 9, 146. [CrossRef] 130. Oak, J.; Spiegel, J.Y.; Sahaf, B.; Natkunam, Y.; Long, S.R.; Hossain, N.; Mackall, C.L.; Kong, K.A.; Miklos, D.B. Target Antigen Downregulation and Other Mechanisms of Failure after Axicabtagene Ciloleucel (CAR19) Therapy. Blood 2018, 132, 4656. [CrossRef]

131. Stoiber, S.; Cadilha, B.L.; Benmebarek, M.-R.; Lesch, S.; Endres, S.; Kobold, S. Limitations in the Design of Chimeric Antigen Receptors for Cancer Therapy. Cells 2019, 8, 472. [CrossRef] [PubMed]

132. Majzner, R.G.; Mackall, C.L. Tumor Antigen Escape from CAR T-Cell Therapy. Cancer Discov. 2018, 8, 
1219-1226. [CrossRef] [PubMed]

133. Visser, J.W.; Martens, A.C.; Hagenbeek, A. Detection of Minimal Residual Disease in Acute Leukemia by Flow Cytometry. Ann. N. Y. Acad. Sci. 1986, 468, 268-275. [CrossRef] [PubMed]

134. Drach, J.; Drach, D.; Glassl, H.; Gattringer, C.; Huber, H. Flow Cytometric Determination of Atypical Antigen Expression in Acute Leukemia for the Study of Minimal Residual Disease. Cytometry 1992, 13, 893-901. [CrossRef] [PubMed]

135. Van Dongen, J.J.; Seriu, T.; PanzerGrümayer, E.R.; Biondi, A.; PongersWillemse, M.J.; Corral, L.; Stolz, F.; Schrappe, M.; Masera, G.; Kamps, W.A.; et al. Prognostic Value of Minimal Residual Disease in Acute Lymphoblastic Leukaemia in Childhood. Lancet 1998, 352, 17311738. [CrossRef]

136. Cavé, H.; van der Werff ten Bosch, J.; Suciu, S.; Guidal, C.: Waterkeyn, C.; Otten, J.; Bakkus, M.; Thielemans, K.; Grandchamp, B.; Vilmer, E.; et al. Clinical Significance of Minimal Residual Disease in Childhood Acute Lymphoblastic Leukemia. European Organization for Research and Treatment of Cancer-Childhood Leukemia Cooperative Group. N. Engl. J. Med. 1998, 339, 591-598. [CrossRef] [PubMed]

137. Porwit-MacDonald, A.; Björklund, E.; Lucio, P.; van Lochem, E.G.; Mazur, J.; Parreira, A.; van den Beemd, M.W.; van Wering, E.R.; Baars, E.; Gaipa, G.; et al. BIOMED-1 Concerted Action Report: Flow Cytometric Characterization of
CD7+ Cell Subsets in Normal Bone Marrow as a Basis for the Diagnosis and Follow-up of $T$ Cell Acute Lymphoblastic Leukemia (T-ALL). Leukemia 2000, 14, 816-825. [CrossRef] [PubMed]

138. Lucio, P.; Gaipa, G.; van Lochem, E.G.; van Wering, E.R.; PorwitMacDonald, A.; Faria, T.; Bjorklund, E.; Biondi, A.; van den Beemd, M.W.; Baars, E.; et al. BIOMED-I Concerted Action Report: Flow Cytometric Immunophenotyping of Precursor BALL with Standardized TripleStainings. BIOMED-1 Concerted Action Investigation of Minimal Residual Disease in Acute Leukemia: International Standardization and Clinical Evaluation. Leukemia 2001, 15, 1185-1192.

139. Krampera, M.; Perbellini, O.; Vincenzi, C.; Zampieri, F.; Pasini, A.; Scupoli, M.T.; Guarini, A.; De Propris, M.S.; Coustan-Smith, E.; Campana, D.; et al. Methodological Approach to Minimal Residual Disease Detection by Flow Cytometry in Adult B-Lineage Acute Lymphoblastic Leukemia. Haematologica 2006, 91, 11091112.

140. Jalal, S.D.; Al-Allawi, N.A.S.; Al Doski, A.A.S. Immunophenotypic Aberrancies in Acute Lymphoblastic Leukemia from 282 Iraqi Patients. Int. J. Lab. Hematol. 2017, 39, 625-632. [CrossRef]

141. Van Lochem, E.G.; van der Velden, V.H.J.; Wind, H.K.; te Marvelde, J.G.; Westerdaal, N.A.C.; van Dongen, J.J.M. Immunophenotypic Differentiation Patterns of Normal Hematopoiesis in Human Bone 
Marrow: Reference Patterns for Age-Related Changes and DiseaseInduced Shifts. Cytom. B Clin. Cytom. 2004, 60, 1-13. [CrossRef] [PubMed]

142. Muñoz, L.; López, O.; Martino, R.; Brunet, S.; Bellido, M.; Rubiol, E.; Sierra, J.; Nomdedéu, J.F. Combined Use of Reverse Transcriptase Polymerase Chain Reaction and Flow Cytometry to Study Minimal Residual Disease in Philadelphia Positive Acute Lymphoblastic Leukemia. Haematologica 2000, 85, 704-710. [PubMed]

143. Huang, A.; Huang, C.; Tang, G.; Cheng, H.; Liu, M.; Ding, J.; Gong, S.; Chen, Q.; Zhang, W.; Yang, J.; et al. Impact of Clinical Utility of MRD Assessment with Different Techniques on Survival in Acute B Lymphoblastic Leukemia. Leuk. Lymphoma 2018, 59, 1073-1083. [CrossRef]

144. Anastasi, J.; Feng, J.; Dickstein, J.I.; Le Beau, M.M.; Rubin, C.M.; Larson, R.A.; Rowley, J.D.; Vardiman, J.W. Lineage Involvement by BCR/ABL in $\mathrm{Ph}+$ Lymphoblastic Leukemias: Chronic Myelogenous Leukemia Presenting in Lymphoid Blast vs. Ph+ Acute Lymphoblastic Leukemia. Leukemia 1996, 10, 795-802. [PubMed]

145. Ravandi, F.; Jorgensen, J.L.; Thomas, D.A.; O'Brien, S.; Garris, R.; Faderl, S.; Huang, X.; Wen, S.; Burger, J.A.; Ferrajoli, A.; et al. Detection of MRD May Predict the Outcome of Patients with Philadelphia Chromosome-Positive ALL Treated with Tyrosine Kinase Inhibitors plus Chemotherapy. Blood 2013, 122, 1214-1221. [CrossRef] [PubMed]

146. Theunissen, P.; Mejstrikova, E.;
Sedek, L.; van der Sluijs-Gelling, A.J.; Gaipa, G.; Bartels, M.; Sobral da Costa, E.; Kotrová, M.; Novakova, M.; Sonneveld, E.; et al. Standardized Flow Cytometry for Highly Sensitive MRD Measurements in B-Cell Acute Lymphoblastic Leukemia. Blood 2017, 129, 347-357. [CrossRef] [PubMed]

147. Cherian, S.; Miller, V.; McCullouch, V.; Dougherty, K.; Fromm, J.R.; Wood, B.L. A Novel Flow Cytometric Assay for Detection of Residual Disease in Patients with BLymphoblastic

Leukemia/Lymphoma Post AntiCD19 Therapy. Cytom. B Clin. Cyłom. 2018, 94, 112-120. [CrossRef] [PubMed]

148. Susman, S.; Berindan-Neagoe, I.; Petrushev, B.; Pirlog, R.; Florian, I.-S.; Mihu, C.-M.; Berce, C.; Craciun, L.; Grewal, R.; Tomuleasa, C. The Role of the Pathology Department in the Preanalytical Phase of Molecular Analyses. Cancer Manag. Res. 2018, 10, 745-753. [CrossRef]

149. Simon, T.; Tomuleasa, C.; Bojan, A.; Berindan-Neagoe, I.; Boca, S.; Astilean, S. Design of FLT3 Inhibitor Gold Nanoparticle Conjugates as Potential Therapeutic Agents for the Treatment of Acute Myeloid Leukemia. Nanoscale Res. Lett. 2015, 10, 466. [CrossRef] [PubMed]

150. Suarasan, S.; Simon, T.; Boca, S.; Tomuleasa, C.; Astilean, S. GelatinCoated Gold Nanoparticles as Carriers of FLT3 Inhibitors for Acute Myeloid Leukemia Treatment. Chem. Biol. Drug Des. 2016, 87, 927935. [CrossRef]

151. Petrushev, B.; Boca, S.; Simon, T.; Berce, C.; Frinc, I.; Dima, D.; 
Selicean, S.; Gafencu, G.-A.; Tanase, A.; Zdrenghea, M.; et al. Gold Nanoparticles Enhance the Effect of Tyrosine Kinase Inhibitors in Acute Myeloid Leukemia Therapy. Int. J. Nanomed. 2016, 11, 641-660. [CrossRef]

152. Gafencu, G.A.; Tomuleasa, C.I.; Ghiaur, G. PARP Inhibitors in Acute Myeloid Leukaemia Therapy: How a Synthetic Lethality Approach Can Be a Valid Therapeutic Alternative. Med. Hypotheses 2017, 104, 30-34. [CrossRef] [PubMed]

153. Dima, D.; Oprita, L.; Rosu, A.-M.; Trifa, A.; Selicean, C.; Moisoiu, V.; Frinc, I.; Zdrenghea, M.; Tomuleasa, C. Adult Acute Megakaryoblastic Leukemia: Rare Association with Cytopenias of Undetermined Significance and P210 and P190 BCR-ABL Transcripts. Onco Targets Ther. 2017, 10, 5047-5051. [CrossRef] [PubMed]

154. Shah, M.Y.; Ferracin, M.; Pileczki, V.; Chen, B.; Redis, R.; Fabris, L.; Zhang, X.; Ivan, C.: Shimizu, M.; RodriguezAguayo, C.; et al. CancerAssociated Rs6983267 SNP and Its Accompanying Long Noncoding RNA CCAT2 Induce Myeloid Malignancies via Unique SNPSpecific RNA Mutations. Genome Res. 2018, 28, 432-447. [CrossRef] [PubMed]

155. Shaver, A.C.; Greig, B.W.; Mosse, C.A.; Seegmiller, A.C. B-ALL Minimal Residual Disease Flow Cytometry: An Application of a Novel Method for Optimization of a Single-Tube Model. Am. J. Clin. Pathol. 2015, 143, 716-724. [CrossRef] [PubMed]

156. Behjati, S.; Tarpey, P.S. What Is next Generation Sequencing? Arch. Dis.
Child. Educ. Pract. Ed. 2013, 98, 236-238. [CrossRef] [PubMed]

157. Pop, L.-A.; Puscas, E.; Pileczki, V.; Cojocneanu-Petric, R.; Braicu, C.; Achimas-Cadariu, P.; BerindanNeagoe, I. Quality Control of Ion Torrent Sequencing Library. Cancer Biomark. 2014, 14, 93-101. [CrossRef] [PubMed]

158. Bahassi, E.M.; Stambrook, P.J. NextGeneration Sequencing Technologies: Breaking the Sound Barrier of Human Genetics. Mutagenesis 2014, 29, 303-310. [CrossRef]

159. Borowitz, M.J.; Devidas, M.; Hunger, S.P.; Bowman, W.P.; Carroll, A.J.; Carroll, W.L.; Linda, S.; Martin, P.L.; Pullen, D.J.; Viswanatha, D.; et al. Clinical Significance of Minimal Residual Disease in Childhood Acute Lymphoblastic Leukemia and Its Relationship to Other Prognostic Factors: A Children's Oncology Group Study. Blood 2008, $111, \quad 5477-5485$.

[PubMed]

160. Conter, V.; Bartram, C.R.; Valsecchi, M.G.; Schrauder, A.; PanzerGrümayer, R.; Möricke, A.; Aricò, M.; Zimmermann, M.; Mann, G.; De Rossi, G.; et al. Molecular Response to Treatment Redefines All Prognostic Factors in Children and Adolescents with B-Cell Precursor Acute Lymphoblastic Leukemia: Results in 3184 Patients of the AIEOPBFM ALL 2000 Study. Blood 2010, 115, 3206-3214. [CrossRef]

161. Logan, A.C.; Zhang, B.; Narasimhan, B.; Carlton, V.; Zheng, J.; Moorhead, M.; Krampf, M.R.; Jones, C.D.; Waqar, A.N.; Faham, M.; et al. Minimal Residual Disease 
Quantification Using Consensus Primers and High-Throughput IGH Sequencing Predicts Post-Transplant Relapse in Chronic Lymphocytic Leukemia. Leukemia 2013, 27, 16591665. [CrossRef] [PubMed]

162. Faham, M.; Zheng, J.; Moorhead, M.; Carlton, V.E.H.; Stow, P.; Coustan-Smith, E.; Pui, C.-H.; Campana, D. Deep-Sequencing Approach for Minimal Residual Disease Detection in Acute Lymphoblastic Leukemia. Blood 2012, 120, 5173-5180. [CrossRef] [PubMed]

163. Ladetto, $M_{\text {.; }}$ Brüggemann, $M_{\text {; }}$ Monitillo, L.; Ferrero, S.; Pepin, F.; Drandi, D.; Barbero, D.; Palumbo, A.; Passera, R.; Boccadoro, M.; et al. Next-Generation Sequencing and Real-Time Quantitative PCR for Minimal Residual Disease Detection in B-Cell Disorders. Leukemia 2014, 28, 1299-1307. [CrossRef] [PubMed]

164. WU, D.; Emerson, R.O.; Sherwood, A.; Loh, M.L.; Angiolillo, A.; Howie, B.; Vogt, J.; Rieder, M.; Kirsch, I.; Carlson, C.; et al. Detection of Minimal Residual Disease in $B$ Lymphoblastic Leukemia by HighThroughput Sequencing of $1 \mathrm{GH}$. Clin. Cancer Res. 2014, 20, 45404548. [CrossRef] [PubMed]

165. Kotrova, M.; Muzikova, K.; Mejstrikova, E.; Novakova, M.; Bakardjieva-Mihaylova, $\quad$ V.; Fiser, K.; Stuchly, J.; Giraud, M.; Salson, M.; Pott, C.; et al. The Predictive Strength of NextGeneration Sequencing MRD Detection for Relapse Compared with Current Methods in Childhood ALL. Blood 2015, 126, 1045-1047. [CrossRef] [PubMed]

166. Pulsipher, M.A.; Carlson, C.;
Langholz, B.; Wall, D.A.; Schultz, K.R.; Bunin, N.; Kirsch, I.; Gastier-Foster, J.M.; Borowitz, M.; Desmarais, C.; et al. $\quad \operatorname{lgH}-\mathrm{V}(\mathrm{D}) \mathrm{J} \quad$ NGS-MRD Measurement Pre- and Early PostAllotransplant Defines Very Lowand Very High-Risk ALL Patients. Blood 2015, 125, 3501-3508. [CrossRef] [PubMed]

167. Gawad, C.; Pepin, F.; Carlton, V.E.H.; Klinger, M.; Logan, A.C.; Miklos, D.B.; Faham, M.; Dahl, G.; Lacayo, N. Massive Evolution of the Immunoglobulin Heavy Chain Locus in Children with B Precursor Acute Lymphoblastic Leukemia. Blood 2012, 120, 4407-4417. [CrossRef] [PubMed]

168. Hrabovsky, S.; Folber, F.; Horacek, J.M.; Stehlikova, O.; Jelinkova, $H_{\text {.; }}$ Salek, C.: Doubek, M.; Czech Leukemia Study Group for Life. Comparison of Real-Time Quantitative Polymerase Chain Reaction and Eight-Color Flow Cytometry in Assessment of Minimal Residual Disease in Adult Acute Lymphoblastic Leukemia. Clin. Lymphoma. Myeloma Leuk. 2018, 18, 743-748. [CrossRef] [PubMed]

169. Keegan, A.; Charest, K.; Schmidt, R.; Briggs, D.; Deangelo, D.J.; Li, B.; Morgan, E.A.; Pozdnyakova, O. Flow Cytometric Minimal Residual Disease Assessment of Peripheral Blood in Acute Lymphoblastic Leukaemia Patients Has Potential for Early Detection of Relapsed Extramedullary Disease. J. Clin. Pathol. 2018, 71, 653-658. [CrossRef] [PubMed]

170. Denys, B.; van der Sluijs-Gelling, A.J.; Homburg, C.; van der Schoot, C.E.; de Haas, V.; Philippé, J.; Pieters, R.; 
van Dongen, J.J.M.; van der Velden, V.H.J. Improved Flow Cytometric Detection of Minimal Residual Disease in Childhood Acute Lymphoblastic Leukemia. Leukemia 2013, 27, 635-641. [CrossRef] [PubMed]

171. Gökbuget, N.; Dombret, H.; Bonifacio, M.; Reichle, A.; Graux, C.; Faul, C.; Diedrich, H.; Topp, M.S.; Brüggemann, M.; Horst, H.-A.; et al. Blinatumomab for Minimal Residual Disease in Adults with B-Cell Precursor Acute Lymphoblastic Leukemia. Blood 2018, 131, 15221531. [CrossRef] [PubMed]

172. Tomuleasa, C.; Selicean, C.; Cismas, S.; Jurj, A.; Marian, M.; Dima, D.; Pasca, S.; Petrushev, B.; Moisoiu, V.; Micu, W.-T.; ef al. Minimal Residual Disease in Chronic Lymphocytic Leukemia: A Consensus Paper That Presents the Clinical Impact of the Presently Available Laboratory Approaches. Crit. Rev. Clin. Lab. Sci. 2018, 55, 329-345. [CrossRef] [PubMed]

173. Jurj, A.; Pop, L.; Petrushev, B.; Pasca, S.; Dima, D.; Frinc, I.; Deak, D.; Desmirean, M.; Trifa, A.; Fetica, B.; et al. Exosome-Carried MicroRNABased Signature as a Cellular Trigger for the Evolution of Chronic Lymphocytic Leukemia into Richter Syndrome. Crit. Rev. Clin. Lab. Sci. 2018, 55, 501-515. [CrossRef] [PubMed]

174. Ciufu, C.; Arama, V.; Bumbea, H.; Dobrea, C.; Ion, I.; Vladareanu, A.M. Correlations of hematological parameters with bone marrow findings in chroniclymphoproliferative disorders associated with hepatitis viruses. J. Med. Life 2013, 6, 464471. [PubMed]

175. Chira, S.; Gulei, D.; Hajitou, A.; Berindan-Neagoe, I. Restoring the p53 'Guardian' Phenotype in p53Deficient Tumor Cells with CRISPR/Cas9. Trends Biotechnol. 2018, 6, 653-660. [CrossRef] [PubMed]

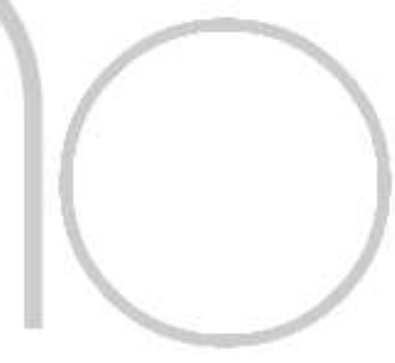

